University of South Florida

DIGITAL COMMONS

@ UNIVERSITY OF SOUTH FLORIDA
Digital Commons @ University of

South Florida

$6-1-2020$

\title{
Safe and Accessible Pedestrian Facility Inventory Model (SAPFIM): Planning and Design
}

CUTR

Follow this and additional works at: https://digitalcommons.usf.edu/cutr_nctr

\section{Recommended Citation}

"Safe and Accessible Pedestrian Facility Inventory Model (SAPFIM): Planning and Design," National Center for Transit Research (NCTR) Report No. CUTR-NCTR-RR-2020-01, Center for Urban Transportation Research, University of South Florida, 2020.

DOI: https://doi.org/10.5038/CUTR-NCTR-RR-2020-01

Available at: https://scholarcommons.usf.edu/cutr_nctr/249

This Statistical Report is brought to you for free and open access by the National Center for Transit Research (NCTR) Archive (2000-2020) at Digital Commons @ University of South Florida. It has been accepted for inclusion in Research Reports by an authorized administrator of Digital Commons @ University of South Florida. For more information, please contact digitalcommons@usf.edu. 


\section{Safe and Accessible Pedestrian Facility Inventory Model (SAPFIM): Planning and Design}

CUTR

Follow this and additional works at: https://scholarcommons.usf.edu/cutr_nctr

\section{Recommended Citation}

"Safe and Accessible Pedestrian Facility Inventory Model (SAPFIM): Planning and Design," National Center for Transit Research (NCTR) Report No. CUTR-NCTR-RR-2020-01, Center for Urban Transportation Research, University of South Florida, 2020.

DOI: https://doi.org/10.5038/CUTR-NCTR-RR-2020-01

Available at: https://scholarcommons.usf.edu/cutr_nctr/249

This Statistical Report is brought to you for free and open access by the National Center for Transit Research (NCTR) Archive (2000-2020) at Scholar Commons. It has been accepted for inclusion in Research Reports by an authorized administrator of Scholar Commons. For more information, please contact scholarcommons@usf.edu. 


\section{TECHNICAL REPORT DOCUMENTATION PAGE}

\begin{tabular}{|c|c|c|c|c|c|}
\hline $\begin{array}{l}\text { 1. Report No. } \\
79061-02-B\end{array}$ & \multicolumn{2}{|c|}{ 2. Government Accession No. } & \multicolumn{3}{|c|}{ 3. Recipient's Catalog No. } \\
\hline \multirow{2}{*}{\multicolumn{3}{|c|}{$\begin{array}{l}\text { 4. Title and Subtitle } \\
\text { Safe and Accessible Pedestrian Facilities Inventory Model (SAPFIM): } \\
\text { Planning and Design }\end{array}$}} & \multicolumn{3}{|c|}{$\begin{array}{l}\text { 5. Report Date } \\
\text { May } 2017\end{array}$} \\
\hline & & & \multicolumn{3}{|c|}{ 6. Performing Organization Code } \\
\hline \multicolumn{3}{|l|}{$\begin{array}{l}\text { 7. Author(s) } \\
\text { Fabian Cevallos }\end{array}$} & \multicolumn{3}{|c|}{ 8. Performing Organization Report No. } \\
\hline \multirow{2}{*}{\multicolumn{3}{|c|}{$\begin{array}{l}\text { 9. Performing Organization Name and Address } \\
\text { Lehman Center for Transportation Research (LCTR) } \\
\text { Florida International University (FIU) } \\
10555 \text { West Flagler Street, EC 3680, Miami, FL } 33174\end{array}$}} & \multicolumn{3}{|c|}{ 10. Work Unit No. } \\
\hline & & & \multicolumn{3}{|c|}{$\begin{array}{l}\text { 11. Contract or Grant No. } \\
\text { DTRT13-G-UTC56; 79061-02-B }\end{array}$} \\
\hline \multirow{2}{*}{\multicolumn{2}{|c|}{$\begin{array}{l}\text { 12. Sponsoring Agency Name and Address } \\
\text { National Center for Transit Research (NCTR) } \\
\text { University of South Florida (USF) } \\
4202 \text { E. Fowler Ave., CUT100 } \\
\text { Tampa, FL 33620-5375 }\end{array}$}} & & \multicolumn{3}{|c|}{$\begin{array}{l}\text { 13. Type of Report and Period Covered } \\
\text { Final Report } \\
\text { June } 2016 \text { - May } 2017\end{array}$} \\
\hline & & & \multicolumn{3}{|c|}{ 14. Sponsoring Agency Code } \\
\hline \multicolumn{6}{|c|}{$\begin{array}{l}\text { 15. Supplementary Notes } \\
\text { Joel Volinski, NCTR Program Director, served as the Project Manager for this project. }\end{array}$} \\
\hline \multicolumn{6}{|c|}{$\begin{array}{l}\text { 16. Abstract } \\
\text { Pedestrian facilities like sidewalks, curb ramps, and crosswalks are critical elements that play a vital role in the life of a } \\
\text { community. Continuous and accessible pedestrian networks improve mobility and livability for all pedestrians and are particularly } \\
\text { important for seniors and pedestrians with disabilities. Pedestrian facilities are instrumental in encouraging walkability, which can } \\
\text { help improve the quality of life of our citizens and the livability of our communities. Therefore, it is critical that local agencies } \\
\text { have access to detailed information of pedestrian facilities to be able to make intelligent decisions. A tool to keep track of } \\
\text { pedestrian facilities can assist local agencies in prioritizing investments for pedestrian improvements: repairs, improvements, and } \\
\text { new construction projects. To accomplish this, there is a need to develop a software tool that can facilitate this effort. }\end{array}$} \\
\hline \multicolumn{6}{|c|}{$\begin{array}{l}\text { The main objective of this project was to plan and design a web-based software application that local agencies can use for the } \\
\text { collection, storage, querying, analysis, and reporting of pedestrian facilities like sidewalks along public roads. Criteria for } \\
\text { determining the accessibility of pedestrian facilities were based on the literature review including the Guidelines for Accessible } \\
\text { Public Rights of Way (PROWAG) and the ADA Standards for Transportation Facilities (ADASTF). This report presents the } \\
\text { research tasks for the planning and design of the Safe and Accessible Pedestrian Facilities Inventory Model (SAPFIM). It includes } \\
\text { a review of the literature, a section on pedestrian facilities, the SAPFIM design including the main data elements, and the next } \\
\text { steps towards the development and deployment of the SAPFIM web-based application. }\end{array}$} \\
\hline \multicolumn{2}{|c|}{$\begin{array}{l}\text { 17. Key Words } \\
\text { Software Application, Pedestrian Facilities, Safety, Accessibility, } \\
\text { ADA, Inventory, Sidewalks, Curb ramps, Crosswalks }\end{array}$} & \multicolumn{4}{|c|}{ 18. Distribution Statement } \\
\hline 19. Security Classif. (of this report) & \multicolumn{3}{|c|}{ 20. Security Classif. (of this page) } & $\begin{array}{l}\text { 21. No. of Pages } \\
51\end{array}$ & 22. Price \\
\hline
\end{tabular}

Form DOT F 1700.7 (8-72)

Reproduction of completed page authorized 


\title{
Safe and Accessible Pedestrian Facilities Inventory Model (SAPFIM): Planning and Design
}

\author{
Submitted by: \\ Fabian Cevallos, Ph.D. \\ Transit Program Director \\ Lehman Center for Transportation Research (LCTR) \\ Florida International University (FIU) \\ 10555 West Flagler Street, EC 3609 \\ Miami, FL 33174 \\ Phone: (305) 348-3144 \\ Email: fabian.cevallos@ fiu.edu
}

\author{
Submitted to: \\ Joel Volinski \\ NCTR Program Director \\ National Center for Transit Research (NCTR) \\ University of South Florida (USF) \\ 4202 E. Fowler Ave., CUT100 \\ Tampa, FL 33620-5375 \\ Phone: (813) 974-9847 \\ Email: volinski@cutr.usf.edu
}

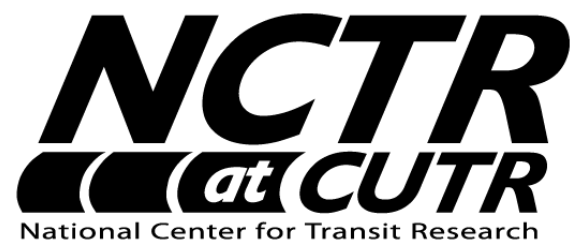

May 2017

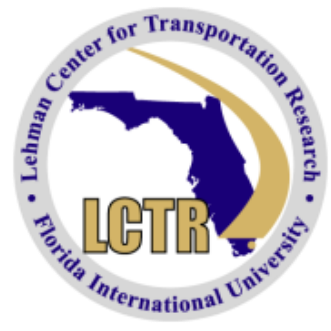




\section{DISCLAIMER}

While every precaution has been taken in the preparation of this document, the publisher and authors assume no responsibility for errors or omissions, or for damages resulting from the use of the information contained herein. The opinions, findings, and conclusions expressed in this publication are those of the authors and not necessarily those of the National Center for Transit Research. 


\section{ACKNOWLEDGMENT}

This research was managed and funded by the National Center for Transportation Research (NCTR) under the direction of Mr. Joel Volinski. We would like to thank Mr. Haifeng Wang, Senior Programmer at the Lehman Center for Transportation Research (LCTR) at Florida International University (FIU), for his expertise in software development and database design; Ms. Thalia Pickering, LCTR Web Designer, for her capability in web design and for her assistance with the documentation; and Ms. Shirin Noei, Ph.D. student, for helping with the literature review.

The project team would also like to recognize the following individuals: Mr. Carey Shepherd with FHWA for his leadership and support of the SAPFIM project; Mr. Dean Perkins with FDOT for his expertize, guidance, and assistance on the development of the SAPFIM data criteria; Ms. Gabrielle Matthews with FDOT for the management and guidance on the matching project and for her assistance with the different meetings and events; and Mr. Peter Gies with the Broward MPO for his active participation in this project. Finally, the project team would like to thank Dr. Fabian Cevallos, LCTR Principal Investigator, for his direction and management of this project. 


\section{LIST OF FIGURES}

Figure 1: Design of SAPFIM Web Application .................................................................... 44

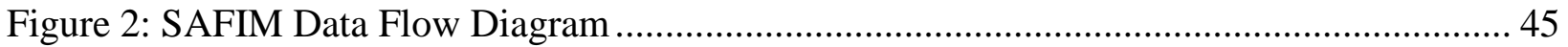




\section{LIST OF TABLES}

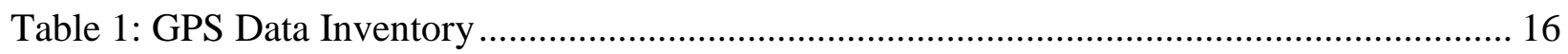

Table 2: Example of State DOT Pedestrian Inventories ........................................................ 22

Table 3: Example of Local Jurisdiction Pedestrian Inventories .............................................. 22

Table 4: Pedestrian Characteristics by Age Group ............................................................... 27

Table 5: Characteristics of Pedestrian-Friendly Communities .................................................. 28

Table 6: Common Residential Traffic Management Program Actions ..................................... 32

Table 7: Common Types of Traffic Calming Methods ........................................................ 33

Table 8: Work Zone Maintenance ............................................................................................ 34

Table 9: Sidewalk Criteria ................................................................................................. 38

Table 10: Curb Ramps \& Blended Transition Criteria ........................................................... 41

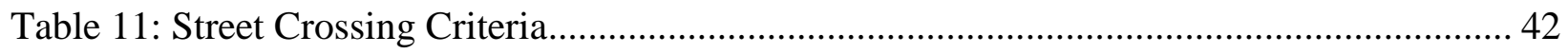




\section{TABLE OF CONTENTS}

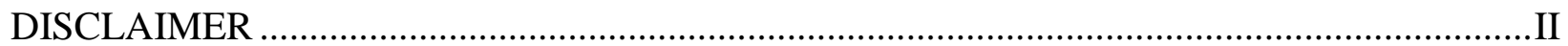

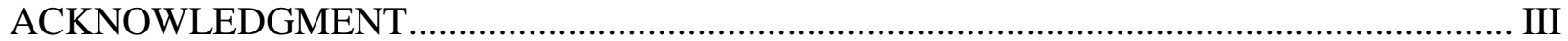

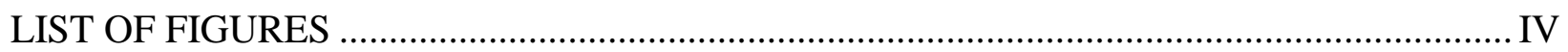

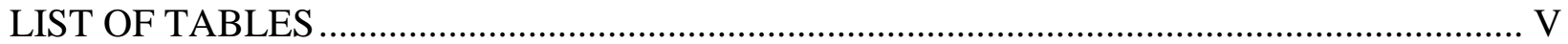

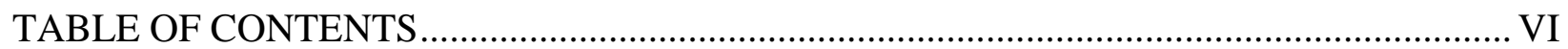

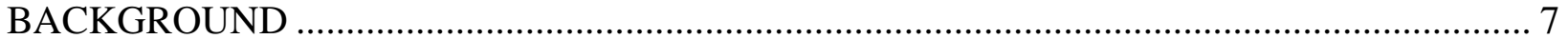

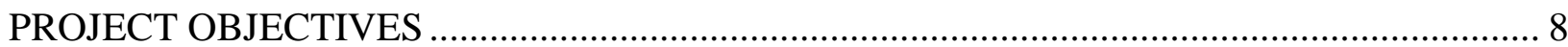

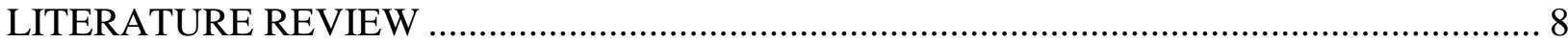

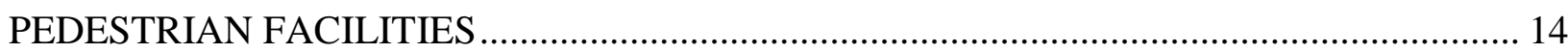

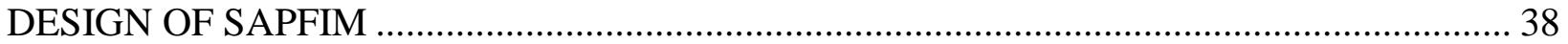

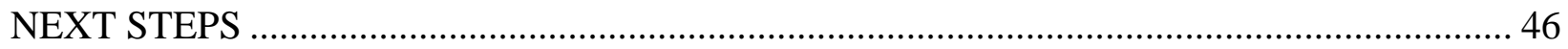

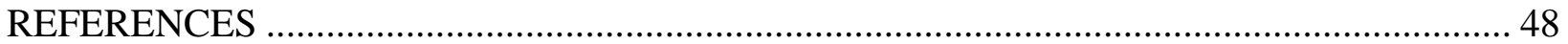




\section{BACKGROUND}

Pedestrian facilities like sidewalks, curb ramps, and crosswalks are critical elements that play a vital role in the life of a community. According to the American Association of Retired Persons (AARP), 8 out of 10 Americans prefer being in a community that offers sidewalks, which provides pedestrians with an accessible and safe path to walk within the public right-of-way separated from motor vehicles and on-road bicycles. Six out of ten prefer a neighborhood that features a mix of residential, commercial, and activities or services within easy access instead of a neighborhood that requires a car for every errand. AARP states that "People who live in neighborhoods with sidewalks are $47 \%$ more likely than residents of areas without sidewalks to be active at least 39 minutes a day".

As pedestrian facilities are critical for pedestrian movement and access, they enhance livability, connectivity, and promote a healthier lifestyle. Further, they benefit communities by promoting social economic activities. Therefore, safe, accessible, and well-maintained pedestrian facilities are a fundamental community investment that enhances public health and maximizes social capital.

Continuous and accessible pedestrian networks improve mobility and livability for all pedestrians and are particularly important for seniors and pedestrians with disabilities. Pedestrians who use sidewalks may have disabilities and may use mobility aids such as wheelchairs, scooters, walkers, canes, etc. Others may have visual impairments (blind or low vision) or have hearing impairments (deaf or hard-of-hearing). According to the Americans with Disabilities Act (ADA) regulations, 28 CFR Part 35, services provided by state and local governments, including features and devices along roadside pedestrian facilities must be "accessible to and useable by" all users, including people with disabilities.

It is often a big challenge for large urban areas to maintain and redesign or repair pedestrian facilities to comply with the Americans with Disabilities Act. It requires a tremendous effort to ensure accessibility for seniors and people with disabilities when these facilities are substandard or poorly maintained. Based on these challenges, agencies are required to develop transition plans to plan and schedule corrections to identified deficiencies. However, planning for the best provisions for accessibility during the process of redevelopment and construction in a number of communities can be challenging. Without readily available and accurate information, pedestrian improvements cannot be easily prioritized.

Pedestrian facilities are instrumental in encouraging walkability, which can help improve the quality of life of our citizens and the livability of our communities. Therefore, it is critical that local agencies have access to detailed information of pedestrian facilities to be able to make intelligent decisions. For example, a computerized pedestrian facilities inventory can easily help identify areas with no sidewalks and document the conditions of existing sidewalks, the level of 
accessibility, and the existence of obstacles or deficiencies that prevent pedestrians to take full advantage of these facilities.

A tool to keep track of pedestrian facilities can assist local agencies in prioritizing investments for pedestrian improvements: repairs, improvements, and new construction projects. To accomplish this, there is a need to develop a software tool that can facilitate this effort. Having a tool available to local agencies can help improve the livability of communities. It can also help identify any safety and accessibility deficiencies that are barriers to senior and pedestrians with disabilities.

\section{PROJECT OBJECTIVES}

The main objective of this project is to plan and design a web-based software application that local agencies can use for the collection, storage, querying, analysis, and reporting of pedestrian facilities like sidewalks along public roads. Criteria for determining the accessibility of pedestrian facilities will be based on the literature review including the Guidelines for Accessible Public Rights of Way (PROWAG) and the ADA Standards for Transportation Facilities (ADASTF).

The Lehman Center for Transportation Research (LCTR) at Florida International University (FIU) has expertize developing web-based systems in the field of transportation. This project is intended to assist with the development a software tool that can be used by local agencies for the assessment of pedestrian facilities. It will include accessible and safety features associated with sidewalks, curb ramps, and street crossings. Data will be collected using field devices (i.e., tablets with GPS, camera, and wireless capability) which can be uploaded directly into the web server.

To achieve the project objectives, the research tasks include a review of the literature, a section on pedestrian facilities, the SAPFIM design including the main data elements, and the next steps towards the development and deployment of the SAPFIM web-based application.

\section{LITERATURE REVIEW}

In this section, the research team identified a series of documents that provide useful information for the understanding, preparation, and development of guidelines and standards as they relate to safe and accessible pedestrian facilities.

The Americans National Standards Institute document (ANSI A117.1, Council of American Building Officials, 1961), originally published in 1961 and reaffirmed without changes in 1971, is one of the building blocks towards addressing issues that deal with accessibility (ANSI, 1961, FHWA, 2004, ICC/ANSI, 2015). A newer and more comprehensive versions of ANSI A117.1 had been released and as of August 2016, the ANSI A117 Committee and the International Code 
Council (ICC) were in the process of a public review of the standard. Passed by Congress in 1968, the Architectural Barriers Act (ABA) (Public Law 90-480) (Goldman, 1968) sets the Federal law requiring new facilities constructed for Federal agencies or with Federal funding to meet accessibility standards (UFAS). Uniform Federal Accessibility Standards (UFAS, Federal Standard 795) define the minimum standards for design, construction, and alteration to meet the requirements of ABA. UFAS is derived from ANSI A117.1-1980 and Access Board's 1982 Minimum Guidelines and Requirements for Accessible Design (MGRAD). The technical specifications of MGRAD were mainly based on the ANSI A117-1980 and the specifications were derived from State accessibility codes, U.S. Access Board research, public review and comments, and existing Federal standards.

In 1973, the passage of the Rehabilitation Act significantly changed the way Federal public policy addresses programs and services for people with disabilities. The Rehabilitation Act of 1973, Title V, Section 504 (Public Law 93-112, amended by PL 516 and PL 95-602) requires federally funded facilities and programs to be accessible to people with disabilities. The Education of All Handicapped Children Act of 1975, now The Individuals with Disabilities Education Act (IDEA), greatly expanded educational opportunities and requiring school accommodations for children with disabilities. Lastly, the passage of the Americans with Disabilities Act in 1990 gave civil rights protection to individuals with disabilities. ADA defines an individual with a disability (ADA, 1990) as a person who has a physical or mental impairment that substantially limits one or more major life activities, has a record of such an impairment, or is regarded by others as having such an impairment.

Americans with Disabilities Act of 1990 (ADA) extended the coverage of ABA, and Rehabilitation Act, Section 504 to include all public facilities regardless of funding. The Title II implementing regulations for ADA requires all newly constructed and altered facilities to be readily accessible to persons with disabilities. Transportation agencies are responsible for developing a transition plan for removing the structural barriers, including communication barriers, and providing access to existing pedestrian facilities. In some States, codes have been adopted that exceed the requirements set forth in the ADA guidelines. In these States, both ADA and the State code must be satisfied. The U.S. Department of Justice (DOJ) and the U.S. Department of Transportation (DOT) use the U.S. Access Board guidelines as a basis to establish accessibility standards. Both the DOJ and DOT may create standards that exceed the recommendations published by the U.S. Access Board. However, they must be consistent with the minimum Access Board guidelines. The standards from then DOJ and DOT are enforceable under the ADA, but the Access Board guidelines are only advisory. The Americans with Disabilities Act Accessibility Guidelines (ADAAG) completed by the U.S. Access Board in 1991, amended in 1998, 2000, and 2002 and is based on specifications established in UFAS and ANSI A117.1

The Intermodal Surface Transportation Efficiency Act of 1991 (ISTEA) specifically called for integrating pedestrian travel into the transportation system. ISTEA increased the Federal-aid 
funding options for pedestrian facilities and programs. In 1998, Transportation Equity Act for the 21st Century (TEA-21) extended the opportunities established in ISTEA and increased funding available for pedestrian facilities. The Accessible Sidewalks and Street Crossings: An Informational Guide from the Federal Highway Administration (2001) go into the details of sidewalk design, but they also provide a good summary of the legal framework as previously discussed.

The Livable Communities for Adults with Disabilities published by the National Council on Disability in 2004 offers a compelling vision for our nation. It articulates the elements of a livable community; highlights existing examples of livable communities in the United States today, which can serve as models for others; and describes how communities can develop and sustain their livability features. Chapter three of this report focuses on accessible, affordable, reliable, and safe transportation system.

In 2005, the Ada County Highway District (ACHD) conducted extensive pre-planning as part of the Pedestrian-Bicycle Transition Plan to ensure that the inventory of existing sidewalk and curb ramp facilities was both cost effective and produced accurate and reliable data for further analysis. The ACHD evaluated a number of GPS products that could collect data electronically for their system inventory. The selected hand-held GPS unit was used for the field data collection. The collected data was formatted and added to the ACHD's geographic information system (GIS) database which allowed for further evaluation and analysis. By successfully deploying the GPSbased data collection effort, ACHD was able to fully inventory the critical pedestrian facilities and prioritize the pedestrian improvements (Transpo Group, 2005).

The Guide for Maintaining Pedestrian Facilities for Enhanced Safety (FHWA, 2013) provides guidance for maintaining pedestrian facilities with the primary goal of increasing safety and mobility. This guide focuses on sidewalks, walkways and curb ramps, shared-use paths, crosswalks, signals, signs, and other treatments of facilities for crossing streets.

Zhang et al. (2014) in the "Develop a Plan to Collect Pedestrian Infrastructure and Volume Data for Future Incorporation into Caltrans Accident Surveillance and Analysis System Database" presented the primary goals to design a flexible database: to store pedestrian and bicycle infrastructure and volume data to be queried in safety analyses, for network deficiencies, and any other uses; to determine an efficient method of collecting data that can be scaled for use across the entire state highway system; to pilot test the data collection process and ensure that all data can be feasibly collected and stored within the database framework; and to estimate the total time-cost of collecting this data across the entire state highway system. This guidance detailed the institutional aspects of the Traffic Accident Surveillance and Analysis System-Transportation System Network (TASAS-TSN) database, including the origins of the database, maintenance procedures, and potential concerns about implementing new variables. It also included a review of literature on direct demand modeling for pedestrians based on transportation network and land-use 
characteristics. This literature aimed to estimate pedestrian volumes throughout the network, which was one potential use of the volume database component of this project.

Further, this Caltrans' guide describes the database developed during this project to store pedestrian and bicycle infrastructure and volume data. The structure used is based on two core elements, nodes and approaches, which provide the spatial structure for the highway network. Nodes correspond to intersections, midblock crosswalks, and points every 1-mile along remote highways (i.e., whenever nodes do not occur for any other reason). Approaches refer to the connections between nodes. Approaches are defined by the direction of motor vehicle traffic, meaning that between two intersections (two nodes) on a bidirectional road, there are two approaches. Secondary elements such as sidewalks, crosswalks, buffer zones, and bicycle facilities are then each related by a unique ID to the approaches and nodes. Separate tables are used for each element type (e.g., approaches, nodes, sidewalks, crosswalks, buffers). It also includes a document describing all of the data elements to be collected for this database in detail. Directions are given for taking different measurements and for classifying categorical information, such as crosswalk types. It describes the pilot data collection process and provides instructions for collecting data in the field. A pilot project was conducted with the goals of refining the data collection process and database format, estimating the total time required to collect data across the entire state highway network, and checking the feasibility of collecting infrastructural data using remote imagery.

Based on the results of the data collection pilot, this report gives an estimate of the time required for collection of pedestrian and bicycle infrastructural data across the entire California state highway network using various data collection processes (computer-based, field-based, and a hybrid approach). Cost estimates are not provided for populating the volume database. Volume data is proposed for collection as part of regular traffic safety investigations and other field visits, as the cost of installing a Miovision camera is very low. The volume data should be collected as frequently as is feasible.

Finally, this report presents conclusions and recommendations for implementation of the data collection process. Areas for future discussion include software for use in implementing the database; whether a GIS-based approach should be considered; connections to the existing TASAS-TSN system; and plans and a timeline for conducting the complete pedestrian and bicycle infrastructure inventory.

FHWA supports flexible design of bicycle and pedestrian facilities. The American Association of State Highway and Transportation Officials (AASHTO) bicycle and pedestrian design guides are the primary national resources for planning, designing, and operating bicycle and pedestrian facilities. In addition, the National Association of City Transportation Officials (NACTO) Urban Bikeway Design and the Institute of Transportation Engineers (ITE) Designing Urban Walkable also provide information on the design of bicycle and pedestrian facilities. Thoroughfares are built upon AASHTO guides, which can help communities plan and design safe and convenient facilities 
for pedestrian and bicyclists. FHWA supports the use of these resources for further development of non-motorized transportation networks, particularly in urban areas

AASHTO published two guides that address pedestrian and bicycle facilities:

- Guide for the Planning, Design, and Operation of Pedestrian Facilities (AASHTO, 2004) provides guidelines for the planning, design, operation, and maintenance of pedestrian facilities, including signals and signing. The guide recommends methods for accommodating pedestrians, which vary among roadway and facility types, and addresses the effects of land use planning and site design on pedestrian mobility.

- Guide for the Development of Bicycle Facilities (AASHTO, 2012) provides detailed planning and design guidelines on how to accommodate bicycle travel and operation in most riding environments. It covers the planning, design, operation, maintenance, and safety of on-road facilities, shared use paths, and parking facilities. Flexibility is provided through ranges in design values to encourage facilities that are sensitive to local context and incorporate the needs of bicyclists, pedestrians, and motorists.

NACTO first released the Urban Bikeway Design Guide in 2010 to address more recently developed bicycle design treatments and techniques. It provides options that can help create complete streets that better accommodate bicyclists. Many of the treatments in the NACTO Guide are compatible with the AASHTO Bike Guide and demonstrate new and innovative solutions for the varied urban settings across the country. The second edition of the NACTO Urban Bikeway Design Guide was published in 2014.

ITE Designing Walkable Urban Thoroughfares - A Context Sensitive Approach: An ITE Recommended Practice (2010) is a useful guide to gain an understanding of the flexibility inherent in the AASHTO Green Book, A Policy on Geometric Design of Highways and Streets. The chapters emphasized thoroughfares in walkable communities (compact, pedestrian-scaled villages, neighborhoods, town centers, urban centers, urban cores and other areas where walking, bicycling and transit are encouraged). It described the relationship, compatibility and trade-offs that may be appropriate when balancing the needs of all users, adjoining land uses, environment and community interests when making decisions in the project development process.

A Livability Fact Sheet of Sidewalks (2014), prepared by the American Association of Retired Persons and the Walkable and Livable Communities Institute (AARP WALC, 2014), gathers some of the studies related to pedestrian facilities. Following is a brief summary of those findings.

- According to the US Centers for Disease Control and Prevention (CDC) study of 2013, People just need safe, convenient, and pleasant places near their homes, schools and workplaces to make walking routine.

- A survey by the Surface Transportation Policy Partnership found that 55 percent of Americans would prefer to walk more and drive less. 
- Sidewalks can be curved to avoid trees. In fact, protecting a tree is one of the few reasons for a sidewalk to deviate from a direct route.

- There is often enough of a public right-of-way easement in place to create a sidewalk without infringing in on a property owner's land.

- Increased pedestrian activity reduces criminal activity; increases property values and tax revenues.

The Livability Fact Sheet of Sidewalks recommends engaging neighbors and the community; making the sidewalk wide enough; using a site-appropriate design; prioritizing high-use areas and connectivity; considering driveways; and maintaining with municipal funds, when advocating and planning for sidewalks.

In the Observations and Recommendations: The Built Environment Albuquerque, New Mexico. Walkable and Livable Communities Institute (WALC, 2014) observations and shortterm/medium-term/long-term recommendations during a visit to Albuquerque are summarized as follows:

- Downtown areas and neighborhoods that aim to improve the ability of people to walk, bicycle, and socialize, should adopt: lower vehicle speeds; narrower vehicle lanes; buildings face front of the street; on-street parking and complete streets.

- Short-term projects considered low-hanging fruit includes moving transit benches out of sidewalks; conducting a public outreach campaign; training department staff; adopting a street design manual; telling the stories; enhancing bicycle parking; and reducing lane widths on wide streets if full road diets are not yet feasible.

- Mid-range projects (the second wave) included the following: putting San Pedro road on a diet; improving the intersection of San Pedro and Constitution; engaging the public and conducting a charrette for San Pedro road; putting Constitution Avenue on a road diet; putting Summer Blvd. on a road diet; starting a weekly growers market; bicycle boulevards; Mark Twain Elementary School; ensuring lighting is placed at all intersections and mid-block crossings; and identifying opportunities for roundabouts.

- Long-range or policy initiatives (the big wins) were: passing a strong complete streets ordinance; creating an Albuquerque destination brand; completing the 50-mile loop; planting street and median trees; completing, improving, and maintaining sidewalks; complying with ADA; partnering with local schools to promote safe routes to school; analyzing the viability of BRT on Central Ave.; working with NMDOT and county officials to improve walkability.

According to the Portland Area Comprehensive Transportation System (PACTS, 2014), walking and bicycling environments should be safe; pedestrian and bicycle network should be accessible and economical; walking and bicycling environment should be clear, easy to use, and attractive to 
enhance community livability; and design guidelines should be applied using professional judgment.

The steps involved in creating a bicycle and pedestrian network plan in the PennDOT Design Manual Part 2 Highway Design (2016) include the following elements: inventorying the existing transportation system; identifying bicycle/pedestrian travel corridors; evaluating and selecting specific route alternatives; identifying design treatments applicable to specific site conditions; and selecting the appropriate facility options to move forward with design and construction.

\section{PEDESTRIAN FACILITIES}

People's abilities vary in agility, balance, cognition, coordination, endurance, flexibility, hearing, problem solving, strength, vision, and walking speed. The design of sidewalk environments is important to all pedestrians, but is particularly important to those with disabilities who have limited travel options and depend on the pedestrian environment.

Barriers restrict the movement of persons to easily navigate within the pedestrian environment. In addition, lack of information makes it difficult for pedestrians to maneuver in this environment. The barriers within a pedestrian environment include curbs, steep slopes, obstacles, and limitations in the design of sidewalks such as widths being too narrow to walk; the information barriers include complex intersections, detours, and general lack of street crossing information.

Assistive technologies enhance the ability of people with disabilities to move freely within the pedestrian environment. Technology can be used to reduce limitations that may exist in the sidewalk environment and include Accessible Pedestrian Signals and engineering treatments like curb ramps, detectable warnings, or push buttons at traffic signals to assist with intersection crossing.

Good sidewalk design should consider the following attributes: accessibility for all users, including those with disabilities; safety, so users do not feel threatened by the adjacent traffic or the pedestrian environment; adequate sidewalk design with landscaping that creates a buffer space between pedestrians and traffic and also provide shade; and provide a social public space to allow people interaction.

In downtown areas, sidewalks need to be designed to accommodate a larger number of pedestrian traffic than in other surrounding areas. Inclusion of streetscapes in downtowns can serve multiple purposes that need to consider the following zones: the building frontage zone, the pedestrian zone, the planter and furniture zone, and the curb zone. The building frontage zone is the area between the building and the pedestrian zone. The pedestrian zone is the area that is specifically reserved for the pedestrian walking activity. The planter and furniture zone is between the curb and the pedestrian travel zone and provides a buffer from the street traffic and allows for the consolidation 
of elements like utilities poles, hydrants, telephone kiosks, etc. as well as street furniture such as benches, shelters, signs. Lastly, the curb zone is the six inches of the sidewalk corridor that is adjacent to the roadway and that also discourages motor vehicles from entering/exiting the sidewalk area.

In reference to sidewalk grades and cross slopes, steep grades and cross slopes should be avoided whenever possible as they can present a problem for wheelchairs and pedestrians with disabilities. There are many factors that play a role on the usability of sidewalks; they include: the materials used for the surface that also have an impact on firmness, stability, and slip resistance; changes in direction and elevation, and dimensions of gaps, grates, and openings. Further, obstacles that protrude into the sidewalk corridor and that are difficult to detect can be problematic to blind pedestrians. Therefore, designers need to keep in mind that as they change the grade of driveway crossings to allow cars to effectively negotiate the grade change between the street and the sidewalk, they must also follow good pedestrian design practices and not compromise the accessibility and safety of sidewalk environments.

Curb ramps can help eliminate the vertical edge of the curb and with detectable warnings, they can mark the boundary between the sidewalk and street. This can be useful for pedestrians with vision impairments and pedestrians who use walking aids such as canes, walkers, or crutches. Wider crosswalks can also enhance the use of curb ramps for all users.

To assist with safe street crossing, audible tones and speech messages at traffic signals can provide WALK, DON'T WALK information to pedestrians. Infrared or Light Emitting Diodes (LED) transmitters can send speech messages in multiple formats to personal receivers including information on the location, direction of travel, and the name of the street to be crossed. In addition, the physical design, placement, and location of the pedestrian signal devices need to be taken into consideration so that the signal device is accessible to pedestrians with vision and mobility impairments (FHWA, 2001).

Designing an effective pedestrian crossing involves the correct layout of pedestrian elements including: information (signs, accessible pedestrian/traffic signals, markings), turning radius, visible crosswalks (including raised crosswalks), adequate crossing times, medians, refuge islands, corner island, curb ramps with detectable warnings, and curb extensions. It also involves careful consideration of adequate sight lines, traffic patterns, and traffic signal phasing. Other techniques such as restrictions on right turns, pedestrian lead times, and traffic calming measures will benefit all pedestrians. Regulations that prohibit parking at the corner can also improve blocked sight lines (ITE, 2010).

According to the Ada County Highway District (ACHD, 2005), the features and characteristics of their GPS data inventory is summarized in Table 1. 


\begin{tabular}{|c|c|}
\hline Feature & Characteristics \\
\hline Sidewalks & $\begin{array}{l}\text { Location, width, cross-slope, material, surface condition, presence of } \\
\text { heaving/cracking, type and number of fixed obstacles within sidewalk, type and } \\
\text { number of movable obstacles located on sidewalk, presence of vertical } \\
\text { obstructions, type of street lighting, type and number of driveway crossings, } \\
\text { presence and type of buffer between street and sidewalk, presence and type of } \\
\text { foliage (trees, shrubs, grasses, etc.), type of street curb }\end{array}$ \\
\hline $\begin{array}{l}\text { Missing } \\
\text { sidewalks }\end{array}$ & $\begin{array}{l}\text { Location, type and number of fixed obstacles in immediate area of future } \\
\text { sidewalk, type of street curb }\end{array}$ \\
\hline Curb ramps & $\begin{array}{l}\text { Location, type, surface condition, material, top landing width and slope, number } \\
\text { of ramps at corner, ramp width, ramp slope, ramp cross-slope, slip-resistant } \\
\text { surface, sidewalk approach, ramp flare slope, gutter slope, crosswalk connection } \\
\text { and alignment, bottom landing width and slope }\end{array}$ \\
\hline $\begin{array}{l}\text { Missing } \\
\text { curb ramps }\end{array}$ & $\begin{array}{l}\text { Location, sidewalk surface condition, material, type and number of fixed } \\
\text { obstacles in immediate area of future curb ramp, location of nearby street drain }\end{array}$ \\
\hline
\end{tabular}

Maintenance is defined as inspecting, preserving, repairing, and restoring a pedestrian facility and keeping it in condition for safe, convenient, and accessible use. Maintenance includes repairing surface defects and changes in level as well as snow/ice, debris, and vegetation removal (Goldman, 1968).

Many jurisdictions have laws or ordinances addressing pedestrian facility maintenance, which often require the adjacent property owner to repair deteriorated sidewalks adjacent to their property. More often ordinances require property owners to remove snow and ice and vegetation encroaching onto sidewalks. However, property owner requirements and enforcement of these regulations may vary widely from jurisdiction to jurisdiction. This is due to a variety of factors including different management structures for maintaining agencies, different legislative requirements, and different climates that require varied approaches to maintenance. Maintenance of shared use paths is more complicated still, because the agencies that are responsible for them do not always make a practice of monitoring them and making sure they are in safe and passable condition.

There are many safety issues that are directly attributable to poorly maintained pedestrian facilities. Improved safety through proper maintenance can be considered in two ways: reduction of crashes with motorists; and the reduction in trips, slip, and falls.

Access and mobility are closely linked. It is difficult to have mobility for a significant segment of the population without providing overall access. Accessible designs are significantly undermined 
if maintenance is neglected and pedestrian facilities are allowed to degrade to a state where they cannot be used or are avoided. There are generally two accessibility issues related to maintenance and both require maintaining an accessible path. First, proper and routine maintenance of walkways allow access between intersections. Secondly, the maintenance of transition points (curb ramps, medians, crosswalks, etc.) ensures access at intersections.

Sidewalks and shared use paths are the main types of pedestrian facilities that accommodate pedestrians. The surface material used for these facilities can have a significant effect on how and how often maintenance is performed. Of the hard surfaces, concrete is the most common surfacing type for sidewalks while asphalt is commonly used for shared use paths. Furthermore, asphalt pavement is often used as a temporary pavement for patching concrete sidewalks.

Bricks and pavers are used to preserve a traditional material and appearance in a downtown or historic district. In some settings pavers are used to border concrete sidewalks. Although these materials tend to be very durable, they do have some unique maintenance issues. Surfaces can also be soft and composed of loose stone, compacted stone dust, or wood chips. Stone surfacing, especially crushed stone is sometimes used for paths and sidewalks. It is more likely that stone or gravel will be used for sidewalks as a temporary fix before a more permanent surface material ultimately replaces it.

Maintenance issues that commonly occur for pedestrian facilities can be sorted into two broad groups: those that are directly related to the pedestrian facility infrastructure itself, such as sidewalk surfacing deficiencies; and those that relate to seasonal or day-to-day maintenance, which require keeping the facility clean and free of nuisance materials. This involves removal of vegetation, snow, ice, sand, and other materials. An effective pedestrian facility maintenance program needs to address both sets of issues.

Infrastructure problems can be broadly categorized into two groups for sidewalks and paths: surfacing problems and structural problems. Both sets of problems cause maintenance issues. Most structural deficits will ultimately affect surface conditions.

Minor surface defects may only affect appearance, but moderate to severe conditions will ultimately become a safety hazard and may significantly affect the usable life of the sidewalk. The most common maintenance problems with hard surface materials result from structural conditions such as those caused by cracking, heaving, tilting, gaps (often at concrete joints), and sidewalk and path sections that either are depressed or raised.

Most of the same maintenance issues impacting sidewalks also impact curb ramps. The most frequent maintenance problem with crosswalk markings is durability. Another durability-related maintenance problem is the conspicuity of pavement markings.

The conditions of sidewalks for safe, comfortable, and accessible travel are influenced not only by 
infrastructure problems, but also by seasonal events such as snowfall, the accumulation of leaf debris, and the overgrowth of vegetation. Maintenance activities to remove obstacles to safe walking are needed to keep sidewalks accessible and hazard-free year-round.

Following a snowfall, snow and ice must be cleared from sidewalks, paths, curb ramps, and crosswalks to provide safe and accessible passage for pedestrians. Most of the problems caused by extreme heat manifest themselves as serious structural problems. Another problem in hot climates is associated with markings. Markings on newly paved streets can be degraded with vehicles tracking over them.

Street trees and other plants adjacent to the sidewalk are a beneficial amenity for a variety of reasons including provision of shade, carbon dioxide reduction, increased property value, storm water control, and visual interest. However, vegetative growth encroaching upon sidewalks or paths is a serious condition that requires maintenance. Sightlines to driveways and intersections must also be maintained for pedestrian safety.

Sidewalk and path inspection criteria serve many useful purposes, especially to reduce slips and falls based on avoidable sidewalk and path hazards. Damaged surfaces and defects can make facilities impassable for everyone and also limit accessibility of people with disabilities or mobility impairments. Other reasons include providing guidelines to agency employees, conveying information to residents, and preventing and/or minimizing lawsuits and liability exposure.

The 2010 ADA Standards (United States Access Board, 2010) are the measure of accessibility for buildings and sites and can be enforced at the Federal level. Some agencies will use these standards for the public right of way to the extent they seem to fit because Public Rights of Way Accessibility Guidelines (PROWAG) is not yet a Federal standard. While this may work in limited circumstances, the 2010 ADA standards do not address the situations commonly found in the public right-of-way such as steep terrain and the constraints of being located next to roadway. They also do not address additional features such as pedestrian signals, crosswalks, refuge islands, on street parking, and the need for detectable warnings at street crossings. The Access Board also establishes the guidelines for buildings and sites, so there is consistency where it is reasonable to use the same criteria.

In the Proposed Accessibility Guidelines for Pedestrian Facilities in the Public Right-of-Way (United States Access Board, 2011), the Architectural and Transportation Barriers Compliance Board is proposing accessibility guidelines for the design, construction, and alteration of pedestrian facilities in the public right-of-way. The purpose of these guidelines is to ensure that sidewalks, pedestrian street crossings, pedestrian signals, and other facilities for pedestrian circulation and use constructed or altered in the public right-of-way by state and local governments are readily accessible to and usable by pedestrians with disabilities.

The guidelines cover pedestrian features in public right-of-ways, including sidewalks and other 
pedestrian ways, street crossings, medians and traffic islands, overpasses, underpasses and bridges. It applies to permanent as well as temporary facilities provides provisions to address Pedestrian Access Routes including Sidewalks, Curb Ramps/Blended Transitions, and Street Crossings.

The Access Board's proposed guidelines address access to newly constructed and altered public streets and sidewalks covered by the American with Disabilities Act and the Architectural Barriers Act (ABA) or the Rehabilitation Act. The guidelines also refer to requirements in the Federal Highway Administration's Manual on Uniform Traffic Control Devices (MUTCD) for Streets and Highways to ensure consistency and to avoid redundancy. Specifically, the guidelines invoke MUTCD definitions and technical criteria for temporary alternate pedestrian routes and pedestrian signals and push buttons. Many of these provisions are designed to ensure that the public rightsof-ways contain a continuous accessible route that accommodates all pedestrians, including those who need mobility aids. These requirements are also expected benefit many other users.

Communities should develop and adopt inspection and maintenance criteria in order to keep the sidewalk facilities in good conditions. The inspections should consider cracks, changes in grade, cross-slopes, vertical clearances, maximum running grades, minimum clear width, and the distance protruding objects extend into the pedestrian path.

Generally, there are two broad accessibility categories related to maintenance and both require maintaining an accessible path. First, proper and routine maintenance of walkways allow access between intersections while the maintenance of intersections (curb ramps, medians, crosswalks, etc.) ensures access at street crossings. Communities will need to balance their needs with the available funding for maintaining pedestrian facilities. A data collection and assessment plan can assist with the prioritization of activities and the decision to either repair or replace the sidewalk facilities. The plan should establish procedures for the public to understand and follow. This should cover how a community repairs facilities, pays for them, informs affected residents, does inspections, establishes projects annually, and schedules repairs.

Routine maintenance consists of day-to-day activities that are scheduled by maintenance personnel to maintain and preserve the condition of facilities at a satisfactory level of service. Corrective maintenance is described as activities that are performed in response to the development of a deficiency or deficiencies that negatively impact the safe, and efficient operations of the facility.

Corrective maintenance activities are generally reactive, not proactive, and performed to restore a facility to an acceptable level of service due to unforeseen conditions. Preventive maintenance consists of treatments to extend the functional condition of a facility. It is typically applied to facilities in good condition having significant remaining service life.

Preventive measures fall into the short and long-term maintenance categories above with the best examples including: mud jacking, joint sealing, grinding, and horizontal cutting for sidewalks; and chip sealing and slurry for asphalt sidewalks and paths. 
When a tripping hazard or obstacle is reported, an agency makes note of the hazard and responds quickly. Multiple falls or complaints about the same area require a city to place a particular sidewalk or street higher on the schedule for repair or replacement. The first step is to inspect the problem location to determine if there is a hazard, as determined by the community's inspection criteria. A follow-up repair is either made on the spot, if a repair crew has been sent to the location to verify it as a hazard, or a repair should be scheduled if an inspector is sent and a legitimate hazard exists. A program associated with a quick response is intended to respond rapidly to problems such as tripping hazards. These problems will be addressed through patching, wedging, crack filling, or even sidewalk replacement. With this program in place, tripping hazards can be responded to in the quickest possible fashion.

To address sidewalk issues in a manageable and predicable fashion, communities should sponsor sidewalk replacement programs that rotate or cycle through a community on a zone-by-zone basis. By concentrating sidewalk replacement into zones, less expensive construction bids for replacement work can typically be negotiated. Alternatively, smaller communities may be able to manage community-wide inspection and replacement programs on an annual basis without a need to split the community into zones.

Communities that fully fund repairs, with no special assessing of impacted properties, have the advantage of being able to move quickly with those repairs. This is also a more equitable way to fund repairs that does not rely simply on the residents that live adjacent to older sidewalks in need of repair.

All requests for sidewalk work or reported hazards should go to the same department and preferably the same person. Every community employee who observes a potential sidewalk or path problem condition should be directed to report it. It is always good policy to document reported problems and how they were resolved. If, after a complaint is received, inspection reveals that a condition does not meet the community's criteria for repair or correction, appropriate documentation should note that.

Some communities are not aware of what pedestrian facilities it owns. Without knowing that, it is difficult to accept ownership for repairs. Every community should have an updated inventory of pedestrian facilities noting the general condition of each facility.

Cities should adopt and follow their own plans and policies, and ordinances for sidewalk inspection and repair. In any form, communities should define what conditions are defective and establish an approach for repair including how the repairs are going to be made and on what type of schedule. There may be times and reasons that a community cannot follow its own policy. At that point, a community should explain and support why it is not following its own established plan or policy along with how they are going to mitigate the impacts.

Initial design and construction methods greatly influence the long-term maintenance and lifespan 
of sidewalks. Historically concrete has been the material of choice by many jurisdictions because of its ease of installation, durability, reliability and availability of materials. The thickness of the sidewalk material, use of reinforcing bars, mesh use of aggregate base, depth of sub-base below the sidewalk, distance from trees, and other design details impact how well a sidewalk will age over time. If best practices are followed, the expected sidewalk materials service life can be as long as eighty years for concrete, bricks, and interlocking concrete pavers; and forty years for asphalt (FHWA, 2013).

Providing an adequate subgrade below sidewalks may deter many of failures by providing stability and good drainage, helping the sidewalk to be more resistant to seasonal changes.

It is important to ensure that sidewalks are constructed with enough thickness to support expected vehicle loading. In some cases reinforcement (usually with a welded wire mesh or rebar) can be used to increase the loading capacity of sidewalks.

Proper sidewalk drainage is important for maintenance purposes and to provide a safe and comfortable experience for users. It is important to provide a slight cross slope on sidewalks to ensure proper drainage and prevent pooling of water, especially in climates where ice can form.

Control and expansion joints should be provided in all concrete sidewalks and paths to minimize cracking and guide where cracking should occur. Asphalt sidewalks typically do not need joints or scoring patterns.

Curb ramps and detectable warning surfaces present unique maintenance needs. The primary issues with detectable warning fields are debris collection, detachment from the sidewalk, or damage to the domes in the warning fields.

Proper site conditions, including soils, tree selection and location are all essential to ensure that the trees thrive in their location and do not interfere with nearby utilities, sidewalks or streets.

A variety of sources are available to fund pedestrian facility inspection and maintenance programs. In general, funding strategies can be split into two categories: programs that are funded by abutting property owners; and programs funded by community taxes, funds, and fees.

Many communities treat pedestrian facilities as a community-wide asset, and fund their repair and maintenance directly. Sidewalk repair and replacement is commonly paid for through the general fund, which is typically funded by property and sales tax revenues. Many communities have downtown or other business district areas that (i.e., business improvement districts, community improvement districts, business improvement area, transportation improvement districts, etc.) have assumed responsibility of sidewalk maintenance, including winter maintenance. These special districts may fund sidewalk maintenance through their general funds or may assess local property owners for general sidewalk maintenance as well as necessary repairs and replacements. 
Means of financing for homeowners association activities is similar to improvement districts or business improvement districts typically through some form of assessment based on valuation.

Assessment programs assess abutting property owners for the costs of maintaining or replacing pedestrian facilities. Property owners may be held responsible for the full cost of the maintenance or the jurisdiction may pay part of cost. If a community does not have a history of assessing property owners for pedestrian facility maintenance, it can be very difficult politically to begin an assessment program. An assessment program requires that the municipality have a system in place to assess property owners for the costs of maintaining abutting pedestrian facilities. In some communities, property owners are directly responsible for maintaining sidewalks, and city ordinances mandate that they schedule and pay for repairs on their own.

A review of pedestrian and bicycle infrastructure inventories carried out in various cities and states are summarized in Table 2 and Table 3 (Source: Zhang et al., 2014).

Table 2: Example of State DOT Pedestrian Inventories

\begin{tabular}{llll}
\hline Inventory & $\begin{array}{l}\text { Year } \\
\text { collected }\end{array}$ & Data recorded & $\begin{array}{l}\text { Size of } \\
\text { system }\end{array}$ \\
\hline Washington & $2002-$ & $\begin{array}{l}\text { Bike lanes, shoulders, shared-used pathways beside the } \\
\text { roadway, sidewalks, walking paths (not worn dirt } \\
\text { paths), signalized and un-signalized intersections, } \\
\text { roadway medians, marked crosswalks, transit stops, and } \\
\text { ADA facilities }\end{array}$ & $\begin{array}{l}\text { miles } \\
\text { New Jersey }\end{array}$ \\
& $2006-$ & $\begin{array}{l}\text { Paths (sidewalks, shared use paths, and worn paths), 13200 } \\
\text { bicycle lanes and routes, shoulders, crosswalks, curb miles } \\
\text { ramps, pedestrian/bicycle related signage, pedestrian } \\
\text { provisions at intersections (e.g. push-buttons and } \\
\text { pedestrian signal heads) }\end{array}$ \\
\hline Maryland & 2007 & $\begin{array}{l}\text { ADA Compliance of sidewalks, bus stops, curb ramps, } \\
\text { driveway crossings, and median treatments }\end{array}$ & $\begin{array}{l}874 \\
\text { sidewalk } \\
\text { miles }\end{array}$ \\
\hline
\end{tabular}

Table 3: Example of Local Jurisdiction Pedestrian Inventories

\begin{tabular}{llll}
\hline City & $\begin{array}{l}\text { Year } \\
\text { collected }\end{array}$ & Data recorded & $\begin{array}{l}\text { Size } \\
\text { system }\end{array}$ \\
\hline $\begin{array}{l}\text { Rancho } \\
\text { Cucamonga, }\end{array}$ & 2011 & $\begin{array}{l}\text { Street name and from/to limits, sidewalk presence, } \\
\text { street light presence, MicroPAVER section ID, } \\
\text { CA }\end{array}$ & $\begin{array}{l}\text { calculated length, estimated width, estimated } \\
\text { surface area, location type (e.g. hospital, library, }\end{array}$ \\
\hline
\end{tabular}




\begin{tabular}{|c|c|c|c|}
\hline & & $\begin{array}{l}\text { school) location proximity- } 500^{\prime}, 1000^{\prime} \text {, and } 1500^{\prime} \\
\text { buffers created around key locations, reasons for } \\
\text { missing sidewalk installation priority ranking }\end{array}$ & \\
\hline Berkeley, CA & 2009 & $\begin{array}{l}\text { Sidewalk presence, sidewalk width, buffer width, } \\
\text { sidewalk condition, marked crosswalk presence, } \\
\text { crosswalk color, crosswalk condition, crosswalk } \\
\text { marking type, crosswalk width, curb ramp } \\
\text { presence, curb ramp type, curb ramp direction, } \\
\text { truncated dome presence, separated pathways, } \\
\text { pedestrian signal features }\end{array}$ & $\begin{array}{l}400 \text { sidewalk } \\
\text { miles }\end{array}$ \\
\hline $\begin{array}{l}\text { Sacramento } \\
\text { County, CA }\end{array}$ & 2007 & $\begin{array}{l}\text { Sidewalk presence, intersection and street corner } \\
\text { measurements and details, mid-block crossings, } \\
\text { bike lane presence, parking type, posted speed } \\
\text { limit, sidewalk conditions, traffic direction (if one- } \\
\text { way), tree spacing in buffer, width of buffer, width } \\
\text { of sidewalk, width of pavement }\end{array}$ & $\begin{array}{l}2200 \\
\text { street/road } \\
\text { miles }\end{array}$ \\
\hline Oakland, CA & 2007 & $\begin{array}{l}\text { Sidewalk damage (type and degree), trees and tree } \\
\text { wells, land use, ADA barriers, parking restrictions } \\
\text { (curb markings), curb/gutter damage, signs, bus } \\
\text { stops }\end{array}$ & Unknown \\
\hline Marina, CA & 2003 & $\begin{array}{l}\text { Pedestrian and bicycle facility deficiencies } \\
\text { reported }\end{array}$ & Unknown \\
\hline Rockville, MD & 2009 & $\begin{array}{l}\text { Curb ramp characteristics, sidewalk locations near } \\
\text { crossings, sidewalk width, sidewalk condition } \\
\text { within crossing area, crosswalk characteristics, } \\
\text { pedestrian signals, signal push buttons, pedestrian } \\
\text { signal timing, pedestrian signing, sight distances, } \\
\text { crossing lighting }\end{array}$ & $\begin{array}{l}162 \\
\text { pedestrian } \\
\text { crossings } \\
\text { analyzed }\end{array}$ \\
\hline $\begin{array}{l}\text { Alexandria, } \\
\text { VA }\end{array}$ & 2009 & $\begin{array}{l}\text { Sidewalk typical width/typical clear width, } \\
\text { sidewalk clear width obstructions, buffer width, } \\
\text { sidewalk surface type, sidewalk surface condition, } \\
\text { driveway crossings, curb ramps (and ADA } \\
\text { compliance), curb radius, type of buffer, on-street } \\
\text { parking type, bicycle rack locations, bus stop } \\
\text { accessibility, bus stop characteristics, roadway } \\
\text { crosswalk type, roadway crosswalk condition, } \\
\text { roadway crossing length, roadway crossing traffic } \\
\text { control type, push buttons, presence of other } \\
\text { crossing facilities }\end{array}$ & 100 miles \\
\hline
\end{tabular}




\begin{tabular}{|c|c|c|c|}
\hline $\begin{array}{l}\text { Piedmont } \\
\text { Triad Rural } \\
\text { Counties, NC }\end{array}$ & 2007 & $\begin{array}{l}\text { Sidewalk condition, sidewalk width, sidewalk } \\
\text { obstructions, curb ramp ADA compliance, } \\
\text { sidewalk material, }\end{array}$ & Unknown \\
\hline Tucson, AZ & 2005 & $\begin{array}{l}\text { Sidewalk category (Accessible, partially } \\
\text { accessible, partial sidewalk, shared-use path, no } \\
\text { sidewalk), roadway functional class, segment } \\
\text { priority ranking (based on variety of factors) }\end{array}$ & $\begin{array}{l}4000 \\
\text { directional } \\
\text { miles }\end{array}$ \\
\hline Asheville, NC & 2005 & Sidewalk presence, curb ramp ADA compliance & Unknown \\
\hline Portland, OR & 1998 & Presence of sidewalks, presence of curb ramps & Unknown \\
\hline $\begin{array}{l}\text { Lexington, } \\
\text { MA }\end{array}$ & & $\begin{array}{l}\text { Sidewalk presence, materials, conditions, major } \\
\text { obstructions }\end{array}$ & Unknown \\
\hline
\end{tabular}

All inventories reviewed have included sidewalk presence as a feature, as it can be determined reliably using aerial photography. Sidewalks are important facilities for providing pedestrian accessibility. Walking on sidewalks is generally much safer for pedestrians than walking along roadways without sidewalks. Additionally, roadway segments with sidewalks along both sides of the road experience lower rates of pedestrian crashes than segments with sidewalks along only one side.

Adequate width is required for ADA compliance. Width is also important in determining whether there is sufficient sidewalk space for the pedestrian volumes present. Wider sidewalks provide more lateral separation between pedestrians and moving vehicle traffic.

Sidewalks in poor condition can lead to impassability for pedestrians with disabilities and can pose a trip hazard for all pedestrians. Sidewalks can be ranked on a scale based on condition, but this would require a field inventory.

Utility boxes, bicycle racks, and overgrown greenery are examples of objects that may block the pedestrian right-of-way. Sidewalk obstructions can be problematic for pedestrians both in terms of inhibiting the path of travel and obscuring pedestrians from drivers' fields of view. Detecting these barriers can likely be completed with Google Street View or reviewing video imagery, or may require a field inventory.

Greater buffer space between moving motor vehicle traffic and the sidewalk (or other pedestrian zone) increases the comfort that pedestrians experience while walking along the roadway. Buffers are typically measured from either the outside edge of the outside travel lane or the curb face to the inside edge of the sidewalk. This measurement can usually be made through review of aerial imagery. Buffers between moving vehicle traffic and the sidewalk may include grass strips, 
bushes, street trees, street furniture, and parked cars. The type of buffer is important because larger objects (such as parked cars) make pedestrians feel safer with respect to adjacent traffic.

Volumes are extremely important for planning purposes, such as for warrants, for safety countermeasures, and for estimating pedestrian risk. While volumes may be estimated for statewide planning purposes, the most accurate figure possible should be collected for analyses of specific locations.

Most transit users travel to transit stops as pedestrians. Information on transit stops may be available via online aerial imagery (Google Maps), or using in street-level imagery.

Providing accessible, affordable, reliable, and safe transportation is such an enormous challenge that some states and counties have been thinking systemically, trying to coordinate all the disparate transportation services and funding streams to create more efficient, cost-effective, and universally accessible transit systems. Realizing that lack of coordination is largely due to the fact that sixty two different federal programs fund transportation, not to mention the proportion of state and local taxes earmarked for transportation, several Federal agencies, including the FTA and the Departments of Health and Human Services, Labor, and Education, have launched a national fiveyear initiative to break down the barriers within human service transportation programs and encourage local partnerships to improve transportation services. One of the components of this initiative is the Framework for Action: Building a Fully Coordinated Transportation System, a comprehensive evaluation and planning tool to help state and community leaders, and agencies involved in human service transportation and transit service, along with their stakeholders, improve or start coordinated transportation systems.

The State of Florida has been working since 1979 to expand transportation services through the Florida Coordinated Community Transportation Program. Broward County, Florida, Transportation Options (TOPS) is an example of coordination at the local level under the leadership of the Florida CTD.

The JAUNT, Inc. Regional Public Transit Agency of Central Virginia was formed in 1975 to meet the transportation needs of area human service agencies. Today, JAUNT serves as a rural service provider, a leader in commuter transportation, a coordinated human service agency transporter, and an urban paratransit provider. JAUNT provides services to the citizens of Albermarle, Fluvanna, Louisa, and Nelson Counties and the City of Charlottesville with a fleet of more than 70 vehicles.

The Sweetwater County, Wyoming public transportation's transit authority (STAR) was created in 1989 and replaced a number of health and human services agency-based transportation services to form a coordinated public transportation system. STAR provides transportation to the general public and to agencies on a contractual basis, and serves the sparsely populated 10,400 square mile area of Sweetwater County in southwest Wyoming. 
In a successful effort led by disability advocates, the faith community, and other CBOs, residents of six cities in Kent County, Michigan, passed a millage increase to fund expanded transportation services that benefit many segments of the population.

Inspired by a California inventor, Charlotte, North Carolina, is pilot-testing an innovative program with portable devices that use GPS satellite technology to empower people with visual impairments to better navigate the city's public transportation system.

According to the news (Boatman, 2015), the city of Los Angeles has reached a tentative agreement with disability advocates to spend $\$ 1.4$ billion to fix crumbling sidewalks that do not provide people who use wheelchairs with the adequate public access required by the ADA.

Communities Actively Living Independent and Free (CALIF) filed the lawsuit in August 2010 advocates. The plaintiffs alleged that Los Angeles discriminated against disabled residents by not fixing damaged sidewalks; not repairing sidewalks with curb cuts that were too steep for wheelchairs; not removing obstructions that blocked sidewalks, such as signs and trees; and not ensuring enough access to public transportation via sidewalks. It is estimated that 40 percent of the sidewalks in Los Angeles are in need of repair.

Damaged sidewalks have been a problem for disabled Los Angeles residents for decades. Many residents of Los Angeles have been involved in accidents related to broken sidewalks. The city has paid over \$6 million in damages related to trip-and-fall lawsuits since 2011.

According to the settlement, the City of Los Angeles has 30 years to repair or replace damaged sidewalks. It is required to spend \$31 million per year to improve sidewalks starting in 2016 and gradually increase it to $\$ 63$ million per year in the future. The settlement also requires the city to pay $\$ 15$ million in attorneys' fees and costs. This settlement is an important victory for disabled residents of Los Angeles. Cities and towns have a responsibility to make sure that their public spaces are accessible to individuals who use wheelchairs in accordance with the Americans with Disabilities Act.

The primary focus of Pedestrian Facilities Guidebook, Washington State DOT (1997), is to encourage good planning, design, and engineering practices related to pedestrian facilities. The guidebook also addresses important construction, ongoing maintenance, and operational aspects related to pedestrian facilities. Following is the summary of this guidebook coming in eleven design toolkits.

Common characteristics of pedestrian collisions are: driver inattention; struck by vehicle while crossing at an intersection (50 percent of all collisions); struck by vehicle while crossing mid-block (33 percent of all collisions); struck from behind while walking along the roadway in the same direction as traffic (particularly in rural areas); motorist exceeding safe speed (contributes to most pedestrian fatalities); darting out into the street at mid- block (most common type of pedestrian 
collision for children); vehicles backing up (difficult to see children and others walking behind); and collisions in urban areas ( 80 percent of all collisions).

Some important needs of pedestrians are: safe streets and walking areas; convenience; nearby places to walk; visibility; comfort and shelter; attractive and clean environment; access to transit; interesting things to look at while walking; and social interaction. Table 4, Washington State Bicycle Transportation and Pedestrian Walkways Plan of 1994, presents common pedestrian characteristics by age group.

Table 4: Pedestrian Characteristics by Age Group

\section{Age Characteristics}
0-4 Learning to walk; requiring constant parental supervision; developing peripheral vision; depth perception

5-12 Increasing independence, but still requiring supervision; poor depth perception; susceptible to dart out/intersection dash

\section{3-18 Sense of invulnerability; intersection dash}

19-40 Active; fully aware of traffic environment

\section{1-65 Slowing of reflexes}

65+ Street crossing difficulty; poor vision ; difficulty hearing vehicles approaching from behind; high fatality rate

Aids to older pedestrians can be: reduced roadway crossing distances (bulb-outs and curb extensions); easy-to-read signs; refuge areas in roadway crossings; traffic calming; shelter and shade; handrails; smooth surfaces and unobstructed travel ways; and signal timing at lower than average walking speed.

Aids to pedestrians with disabilities can be: curb cuts and ramps; tactile warnings; easy-to-reach activation buttons; audible warnings and message systems; raised and braille letters for communication; signal timing at lower than average walking speed; roadway crossing refuges; reduced roadway crossing distances (bulb-outs and curb extensions); traffic calming; handrails; and smooth surfaces and unobstructed travel ways.

Urban areas that have high pedestrian use are due to: higher densities of residences, businesses, and other origins and destinations; traffic congestion; high concentrations of origin and destination points; shopping and services are more accessible to pedestrians; average trip distances are shorter; 
parking is too costly or unavailable; transit service is more readily available; and more available pedestrian facilities.

According to Washington State Bicycle Transportation and Pedestrian Walkways Plan of 1994, common reasons for low levels of pedestrian travel are: poor facilities; lack of sidewalks or walkways; failure to provide a contiguous system of pedestrian facilities; concerns for personal safety; failure to provide facilities to and from popular origins and destinations; inclement weather, poor lighting; and lack of separated facilities.

Pedestrian facilities and features include sidewalks; trails; curb ramps; traffic calming and control devices; grade-separated crossings; wide shoulders and other technologies; design features; and strategies intended to encourage pedestrian travel. State policies can encourage pedestrian travel through: addressing pedestrian issues using comprehensive planning; considering pedestrian needs in all transportation facilities; reinforcing a sense of neighborhood and community with transportation designs that accommodate pedestrian use; ensuring a connected system of pedestrian routes in urban areas; enhancing pedestrian mobility and safety in rural areas; defining jurisdictional roles in providing pedestrian facilities; encouraging land use and transportation development that accommodates pedestrians; providing pedestrian facilities that complement local business activity and provide access for employees; enhancing intermodal access for persons with impaired mobility; and maintaining the existing transportation system adequately so pedestrian use is maximized. Some common characteristics of pedestrian-friendly communities are listed in Table 5 (Pedestrian Guidebook Facilities, 1997).

Table 5: Characteristics of Pedestrian-Friendly Communities

Coordination Putting pedestrian facilities in place to meet current and future needs requires close coordination between jurisdictions and other modes of transportation.

\begin{tabular}{ll}
\hline $\begin{array}{l}\text { Regional } \\
\text { Connectivity }\end{array}$ & $\begin{array}{l}\text { Pedestrian circulation and access is provided to shopping malls, transit, } \\
\text { downtown, schools, parks, offices, mixed-use developments, and other } \\
\text { community origins and destinations, as well as other communities within } \\
\text { the region. }\end{array}$ \\
Connectivity & $\begin{array}{l}\text { A complete system of interconnected streets, pedestrian walkways, and } \\
\text { other pedestrian facilities will increase pedestrian travel. }\end{array}$ \\
Convenient access & $\begin{array}{l}\text { Connections are provided between popular origins and destinations, } \\
\text { between dead-end streets or cul-de-sacs, or as shortcuts through open } \\
\text { spaces. }\end{array}$ \\
Continuous & $\begin{array}{l}\text { Minimized or eliminated street and driveway crossings are provided and } \\
\text { well defined. Buffers from motor vehicles and separation of uses are } \\
\text { provided }\end{array}$
\end{tabular}




\begin{tabular}{ll}
\hline Pedestrian & Land use patterns, such as a grid layout or short blocks in business \\
supportive land- & districts and downtowns enhance pedestrian mobility. \\
use patterns &
\end{tabular}

\section{Well-functioning} facilities
Adequate width and sight distance, accessible grades, and alignment to avoid blind corners are provided. Common problems, such as poor drainage, are avoided.

\section{Designated space Pedestrian facilities should be well delineated, signed, and marked.}

Security

Not only automobile

Neighborhood traffic calming
Design to ensure a secure environment for pedestrians is important. Lighting, increased visibility, open sight lines, and access to police and emergency vehicles.

Streets are designed for all modes of transportation. Parking supply is reduced or managed using methods that encourage walking.

Narrowed streets lined with trees, traffic circles, curb bulbs, neck- downs, and other techniques can lower vehicle speeds and create safer conditions for pedestrians.
Accessibility

Lively public spaces
Siting of transit facilities adjacent to work, residential areas, shopping, and recreational facilities encourages pedestrian trips. Transit stops and centers should typically be located in areas of supporting densities. Development of adequate pedestrian facilities to access transit is essential to their success as an alternative mode of travel.

Secure, attractive, and active spaces provide focal points in the community where people can gather and interact. Pedestrian pocket parks and plazas are examples.

Character

Preservation of important cultural, historic, and architectural resources strengthens community heritage and character.

\section{Scenic} opportunities

\section{Pedestrian} furnishings
Attractive environments and scenic views encourage pedestrian use, particularly when facilities are oriented toward them.

Providing furnishings, such as benches, restrooms, drinking fountains, artwork and other elements, creates a more attractive and functional environment for pedestrians.
Street trees bring human scale to the street environment. Landscaping and flowers in planting strips, containers, and other areas soften surrounding hard edges of buildings and parking lots and add life, color, and texture to the pedestrian's field of vision. 


\section{requirements justified and documented.}

\section{Proper \\ Frequent cleanup and repair on a regular basis ensures consistent use. maintenance}

Typical elements of pedestrian-friendly streets are: streets that are interconnected and small block patterns provide good opportunities for pedestrian access and mobility; narrower streets, scaled down for pedestrians and less conducive to high vehicle speeds; traffic calming devices to slow traffic, or reduced speed limits; median refuge islands to provide a refuge area for crossing pedestrians; public spaces and pedestrian pockets adjacent to the main pedestrian travel way, that provide a place to rest and interact (sidewalk cafes, benches, etc.); awnings/covered building entrances that shelter pedestrians from weather; planting buffers, with landscaping and street trees that provide shelter and shade without obstructing sight distances and help to soften the surrounding buildings and hard surfaces; street lighting designed to pedestrian scale (shorter light poles with attractive fixtures that are effective in illuminating the pedestrian travel way but not obtrusive or harsh); wide and continuous sidewalks or separated walkways that are fully accessible. Clear delineation and direction for the pedestrian (special paving on sidewalk or at edge of pedestrian travel area, easy-to-reach signal actuators, etc.); lively building faces with architectural relief, windows, or attractive surfacing; street furnishings, such as benches, garbage receptacles, drinking fountains, and newspaper stands, if not placed in the route of travel; public art, murals, banners, sculpture pieces and water features; colorful planters, holiday lighting and other attractive features; signs, information kiosks, maps, and other elements to help pedestrians.

Accessibility Design for All-An Illustrated Handbook, Washington State Regulations (1995), defines accessible route of travel as a continuous unobstructed path connecting all accessible elements and spaces in an accessible building or facility than can be negotiated by a person using a wheelchair and that is usable by persons with other disabilities (includes access routes across sites between building entrances and other public facilities such as parking, sidewalks, restrooms, etc.).

Most common types of pedestrian/motor vehicle collisions for children aged K-6 are: darting out; dashing across an intersection; crossing in front of a turning vehicle; crossing a multi-lane street; entering or crossing an intersection; playing in a roadway; going to or from a school bus; and crossing behind a vehicle that is backing up. In this case, recommended processes for improving student pedestrian safety are: preparing school walk route plans; providing school walk route maps and information to parents and students; identifying pedestrian safety deficiencies; and implementing remedial actions and improvements to address pedestrian safety concerns. Pedestrian improvements along school walk routes can be: well-compacted crushed rock or gravel shoulders, separated crushed rock or gravel path, paved shoulder, paved walkway or sidewalk separated from roadway by ditches, swales, or planting buffers. As some of these improvements 
are a short-term solution, a long-term solution need to be considered for the route of travel to be accessible. For this, the surface needs to be smooth and stable with edge treatments when necessary.

Separation treatments for multi-use pathways can be: colored paving; signing; textured paving or paving patterns; pavement markings; and striping with education program about trail use and other measures.

According to the Design and Safety of Pedestrian Facilities, A Proposed Recommended Practice of the Institute of Transportation Engineers, ITE Technical Council Committee TENC 5A-5 (1998), criteria to be analyzed to determine pedestrian safety deficiencies are: roadway and traffic control device inventory; sight distance studies; adequacy of gaps in the stream of traffic for pedestrian crossings; collision summaries and diagrams; conflict analysis; pedestrian volumes and characteristics; and traffic volumes and speeds.

Based on the Oregon Bicycle and Pedestrian Plan (1995), access management techniques can be: reducing the number of existing driveways or consolidating driveways to parking areas and businesses; and providing raised or landscaped medians or concrete barriers to control turning movements from the street. Furthermore, some of the access management benefits are: the number of conflict points is reduced (e.g., the use of center medians to reduce the number of conflicts between left-turning vehicles and pedestrians); pedestrian crossing opportunities are enhanced with an accessible raised median and fewer conflicts with turning cars; accommodating people with disabilities becomes easier with the reduced need for special treatments at driveway cuts; traffic volumes may decrease if local traffic can use other available routes; and improved traffic flow may reduce the need for road-widening, and reducing the number of lanes to cross at intersections, allowing more space for use by pedestrians and bicyclists.

Basic principles of intersection design to accommodate pedestrians are: intersections that function well for pedestrians are typically compact; free-flowing motor vehicle movements are either eliminated or vehicles are forced to a significantly slower speed through the intersection; all legs of an intersection should be available for pedestrian use; closing a crosswalk doesn't necessarily prevent pedestrians from crossing in that direction. Pedestrians need to be able to travel in a direct line across the intersection and the direction of travel needs to be clearly identified for all pedestrians, including those with sight impairments, avoiding increasing potential conflicts or the level of pedestrian exposure to motor vehicles. Note that on some T-intersections, it may not be desirable for pedestrians to cross in front of left turning vehicles.

Basic conditions that are considered for the installation of pedestrian crossing improvements are: school walking routes; routes identified in the non-motorized plan; connection to significant business areas; access to transit; higher level of protection or better sight distance or otherwise easier to cross; serving people who have more difficult than average crossing the street; a safety 
problem that can be solved by improving the crosswalk.

Medians and refuge islands should have a desirable width to prevent wheelchairs pushed by assistants, bicyclists, and people with strollers from projecting out into the stream of vehicular traffic. In some cases, smaller width medians and refuge islands may be acceptable, particularly when there is limited space in the right-of-way, depending on local requirements and existing conditions. In order to obtain appropriate median width, travel lanes can be narrowed if allowed by local standards.

Trees in medians and at the sides of streets can help to narrow the long range field of vision for approaching drivers, causing them to slow down as they near the crossing point. Landscaping in median refuge islands must be handled carefully. It is essential that landscaping not block the sight lines of pedestrians and motorists at the crossing area.

Curb ramps or full-cut through should be considered to meet ADA requirements for median refuge islands. The most common are cut-throughs because median widths are usually not large enough to accommodate ramps. A pedestrian push button should be placed in the median of signalized mid-block crossings where the crossing distance exceeds 60 feet. Further, the use of angled refuge areas in the island should be considered to encourage pedestrians to look in the direction of oncoming traffic, helping them to be more aware of approaching vehicles. Lastly, it is recommended that medians and refuge islands be illuminated.

A Guidebook for Residential Traffic Management, published by Washington State DOT (1994), identified references to individual traffic control devices or measures that have been used for residential traffic management. Table 6 illustrates common actions of residential traffic management programs and Table 7 illustrates some of the most common types of traffic calming methods.

Table 6: Common Residential Traffic Management Program Actions

\begin{tabular}{|c|c|c|}
\hline Reducing & By what means & Examples \\
\hline Traffic volumes & Physical & Traffic circles; traffic diverters \\
\hline Vehicle noise & Psychological & Variable-spaced paint stripes \\
\hline Visual impacts & Visual & Landscaping to block through views \\
\hline Traffic speeds & Social/physical & $\begin{array}{l}\text { Neighborhood "speed watch" program; speed } \\
\text { humps/tables }\end{array}$ \\
\hline Collisions & Legal/physical & Strict speed enforcement; spot safety improvements \\
\hline
\end{tabular}




\title{
Table 7: Common Types of Traffic Calming Methods
}

\begin{tabular}{ll}
\hline Technique & Description \\
\hline Traffic circles & $\begin{array}{l}\text { Circular raised islands centered within intersections. Circles can be } \\
\text { landscaped or surfaced with special paving. Landscaping can be } \\
\text { maintained by the local jurisdiction or by neighborhood volunteers. }\end{array}$ \\
Chicanes & $\begin{array}{l}\text { Alternately placed curb extensions into the street that force motorists } \\
\text { to drive in a serpentine pattern. Chicanes are offset from each other in } \\
\text { mid-block locations and can be used to keep through-trucks versus } \\
\text { local delivery off residential streets. }\end{array}$
\end{tabular}

\begin{abstract}
Curb bulb-outs, chokers/neckdowns

Curb extensions placed at mid-block locations or intersections, which narrow the street to provide visual distinction and reduce pedestrian crossing distances. Bulb-outs help to provide a clear visual signal to drivers that a crossing is approaching and makes waiting pedestrians more visible. Neckdowns are often longer than bulb-outs and often line up with and help to define parallel street parking areas. They narrow the appearance of the street and can be attractive, especially when landscaped.

Diagonal diverters

Eliminates through traffic while providing partial access in opposite directions; island can become amenity and provide refuge for pedestrians.
\end{abstract}
Forced turns and Truncated diagonal diverters (one end remains open) and other types partial diverters of partial diverters discourage commuter traffic by forcing turns, but provide local access opportunities.
Cul-de-sac/street closures
Street is closed and turned into a cul-de-sac; end of street becomes a neighborhood amenity and focal point (landscaped mini park); the ongoing provision of pedestrian and bicycle access is important.
One-way entry and Curb bulbs/extensions are used to close one lane of traffic at exit intersections; stops through traffic but allows ingress or egress depending on the direction and location of the closure.
Narrower streets
Narrower streets limit the expanse of pavement visible to the driver and can be effective in slowing traffic, especially when lined with trees or on-street parking.

\begin{tabular}{ll} 
Speed humps/tables & $\begin{array}{l}\text { A speed hump is wider and smoother than a speed bump, and effective } \\
\text { in slowing cars as they approach pedestrian zones. These are most } \\
\text { appropriately used on neighborhood streets. }\end{array}$ \\
$\begin{array}{l}\text { Signs and } \\
\text { neighborhood }\end{array}$ & $\begin{array}{l}\text { Signs such as "Residential Street," "Local Access Only", or } \\
\text { monuments that identify neighborhood districts can be effective, }\end{array}$ \\
\hline
\end{tabular}


gateways

Special paving

Speed watch programs especially when used conjunction with other techniques, including those listed above and others, such as pavement markings and textured warning strips.

Alternative road surfaces, such as brick, colored concrete or special pavers, can be used at crossings, intersections, or along the sides of the street to break up the visual expanse of pavement and define areas of pedestrian travel.

Citizens and organizations can utilize a radar device and electronic signboard to measure speeds of passing vehicles in their neighborhoods. Letters of warning can be sent to the registered owners of offending vehicles. These programs promote neighborhood.

Low-cost improvements to increase pedestrian access to transit are: pavement markings where sidewalks or other pedestrian facilities do not exist; marked crosswalks; removal of sidewalk obstructions; and changes in signal phasing at intersections and crossings near stations and bus stops.

Delineated walkways through parking lots; connections to neighborhoods and surrounding areas; easy to identify building entrances and building frontages located along streets rather than across parking lots; convenient and safe access to transit and adjacent sidewalks; alignment of walkways for convenience and reduced travel distances; accessible routes of travel to and from the site, as well as throughout the site; and no barriers (walls, ditches, landscaping, or roads without safe crossings) to pedestrian travel are common features of a pedestrian-friendly site design.

Separating pedestrians from conflicts with construction vehicles, equipment, and operations; separating pedestrians from conflicts with traffic traveling around or through the construction area; providing a safe, convenient, and accessible route that maintains the direction and character of the original route; minimizing work vehicle traffic crossing pedestrian routes by minimizing the number of construction access points; communicating construction activity and pedestrian impacts through local media and pedestrian interest groups; and avoiding using delineating materials that are difficult to recognize by people with impaired sight are common considerations for pedestrian safety in work zones. Bicycle and Pedestrian Facilities Planning and Design Guidelines, North Central Texas Council of Governments summarizes work zone maintenance issues and recommendations as in Table 8 .

Table 8: Work Zone Maintenance

Issue Recommended maintenance

Temporary pathways Pathway surfaces should be inspected regularly; surface constructed of inexpensive, materials should be treated with nonslip materials; surface 


\begin{tabular}{ll}
\hline short-life materials & $\begin{array}{l}\text { materials with holes, cracks, or vertical separation should be } \\
\text { replaced }\end{array}$ \\
$\begin{array}{l}\text { Detour pedestrian paths } \\
\text { increase volumes on detour } \\
\text { roadway }\end{array}$ & $\begin{array}{l}\text { Detour pathway should be inspected regularly for adequacy of } \\
\text { signal timing, signing, and pedestrian traffic hazards }\end{array}$ \\
$\begin{array}{l}\text { Construction material debris } \\
\text { on pathway }\end{array}$ & Require contractor to maintain clear pathways \\
$\begin{array}{l}\text { Changing pedestrian route } \\
\text { during construction }\end{array}$ & $\begin{array}{l}\text { Inspect pedestrian signing regularly to ensure a clearly } \\
\text { understood pathway }\end{array}$ \\
\hline Damaged traffic barriers & Replace and reevaluate adequacy for pedestrian safety \\
\hline
\end{tabular}

Pedestrian facilities are limited to pedestrian use only:

- Sidewalks

- A pedestrian lane that provides space to travel within the public right-of-way that is separated from roadway vehicles. PennDOT's Design Manual requires sidewalks to be a minimum of five feet in width to comply with ADA requirements.

- Sidewalks are primarily for pedestrian use only; exceptions for bicycles may include use by small children or where no other option is available (such as narrow bridges where bicycles may be expressly permitted).

- Based on Revised Code of Washington (RCW) (1992), sidewalk is a property between the curb lines in the lateral line of a roadway and adjacent property, set aside and intended for the use of pedestrians or such portion of private property parallel and in proximity to public highway and dedicated to use by pedestrians.

- Internal walkway

- A designated single-use facility with an improved surface, primarily for use by pedestrians, typically located outside of the road right-of-way and/or not directly adjacent to a street and generally used to facilitate pedestrian transportation between buildings and parking areas or sidewalks, between buildings on a parcel or within a development, or between adjacent uses, developments, or facilities.

- Social path/trail

- An informal, unimproved path typically, of bare earth worn in grassy areas formed by pedestrians repeatedly traveling between areas where no trails, sidewalks, or pedestrian paths have been installed. The point of defining social paths is to require their identification during the subdivision and land development process and requiring that consideration be given to formalizing them into sidewalks, internal 
walkways, or trails as a part of new development to facilitate pedestrian movement within a site and connections to adjacent areas.

- Use-restricted path

- Paths are typically unpaved trails that are primarily used for one form of travel. Most commonly, single-use paths are designated for pedestrian/hiking purposes only due to trail width, surface, topography, condition, accessibility limitations, and potential user conflict.

Bicycle Facilities are limited to bicycle use only:

- Shared roadway (with limited, inconsistent, or no shoulder)

- A roadway accommodating bicyclists and motorists in the same travel lane. Typically the travel lanes are wider than what would be designed for automobile traffic only for the associated functional classification of the road and its context (e.g. rural or urban).

- Shared roadways may be a Signed Bike Route or include other indicators such as Share the Road Signs, Sharrows, or other pavement markers.

- Shared roadway with paved shoulder

- The street with a paved shoulder or wide curb lane that accommodates bicyclists adjacent to the vehicle travel lanes. A four to six foot shoulder is preferable, in conjunction with applicable municipal and PennDOT guidelines.

- Paved shoulders are separated from travel lanes by the striping representing the outside edge of the outermost travel lane.

- Bike lane

- A designated travel lane along the shoulder for exclusive use by bicyclists. Bicycle lanes are typically located on roadways in urban and suburban settings with moderate to high vehicular traffic volumes and moderate to high-posted speeds.

- PennDOT's Design Manual requires a formal bicycle lane to have a five-foot dedicated shoulder, application of pavement striping, markings, and regulatory signage. Bicycle lane facilities should be one-way facilities that carry traffic in the same direction as motor vehicles.

In addition to the shared roadway and bike lane facilities, supplemental signage, roadway treatments (striping, coloration, or texture) can be added to these facilities when warranted.

- Share the Road

- A supplemental signage added to a shared roadway to warn motorists of the increased likelihood of bicyclists.

- Sharrow

- A pavement marker that increases driver awareness of shared roadway arrangements. 
- Signed bicycle route

- A treatment used to designate a preferential bicycle routing and provide guidance to cyclists. AASHTO's Guide for the Development of Bicycle Facilities states that the signing of shared roadways indicates to cyclists that there are particular advantages to using these routes compared to alternate routes.

- Route signs can be used to provide directional, distance, and destination information to assist bicyclists in navigation. Signed routes can also be used to direct cyclists to corridors that have existing on-road facilities, or access locations for off road facilities.

- Bicycle boulevard

- A corridor treatment that prioritizes bicycle travel via traffic calming measures, signs, pavement markings, and crossing improvements to enhance bicycle travel.

- Cycle track

- An exclusive facility for bicyclists that combines design aspects of bike lanes and shared-use trails. Shared-use facilities accommodate users of different modes on the same facility:

- Shared use/multi-use trail

○ A facility that is physically separated from the roadway and typically accommodates bi-directional travel by both bicyclists and pedestrians. The trail can be located within a publicly owned right-of-way, an exclusive right-of-way, or an easement.

- Shared-use paths typically have an improved surface (e.g., asphalt, concrete, compacted gravel, etc.) and have a recommended width per AASHTO of ten feet, although a minimum width of eight feet may be used where space is constrained or in environmentally sensitive areas.

- Sidepaths are a subset of shared use paths that denote paths that run adjacent to a parallel roadway. Sidepaths can provide bicycle connections between on- and offroad facilities, but often require a more in-depth operational and safety analysis.

- Mid-block crossing

- A mid-block crossing permits pedestrians and bicyclists to cross a road at a location other than an intersection. These crossing require special engineering analysis to determine their appropriateness and effectiveness.

The ADA for Roadway Design Incorporating PROWAG presented by Dean Perkins (2015) provides a concise background on ADA standards and recommends using the PROWAG criteria if ADA Standards do not address a particular issue. The document contains information concerning safety and accessibility criteria on pedestrian access routes. It emphasizes that public services must be accessible since the public uses them. Further, it mentions that sidewalks and curb ramps should be accessible and that the elements and features along sidewalks, curb ramps, and crossings should follow the ADA or PROWAG criteria. 


\section{DESIGN OF SAPFIM}

The design of the SAPFIM application starts with the collection of the key Sidewalks, Ramps, and Crossings data elements for the creation of the SAPFIM Criteria. The data elements identified in the SAPFIM Criteria will help categorize the data fields that will need to be collected and measured considering both the ADA and PROWAG standards. Further, these data fields will be used in the development of the user interface and database of the SAPFIM web application. The selection of the data fields and development of the SAPFIM Criteria was based on the work of Dean Perkins (2015), literature review, information gathered by the research team, and the feedback from the agencies and stakeholders involved in this research project.

Tables 9, 10, and 11 present the pertinent SAPFIM criteria elements for the three selected categories: Sidewalks, Curb ramps \& Blended Transition, and Street Crossing. These tables include the following categories: Name, Description, Detail, Measurement, and ADA, and PROWAG Standards. The information provided in each of these categories will help with the preparation of the field data collection elements and the understanding of the associated safety and accessibility features.

Table 9: Sidewalk Criteria

\begin{tabular}{|c|c|c|c|c|c|}
\hline \multicolumn{6}{|c|}{ Sidewalks (Street Name, Side) (Photos) } \\
\hline Name & Description & Detail & Measurement & $\begin{array}{c}A D A \\
\text { Standard }\end{array}$ & $\begin{array}{c}\text { Public Rights- } \\
\text { of-Way } \\
\text { Accessibility } \\
\text { Guidelines } \\
\text { (PROWAG) }\end{array}$ \\
\hline Sidewalk & Sidewalk & $\begin{array}{l}\text { Is there a } \\
\text { Sidewalk? }\end{array}$ & Yes/No & & \\
\hline $\begin{array}{l}\text { Sidewalk } \\
\text { Width }\end{array}$ & $\begin{array}{l}\text { General } \\
\text { Width }\end{array}$ & & $\begin{array}{l}<36 " \\
\geq 36 "<48^{\prime \prime} \\
\geq 48^{\prime \prime}\end{array}$ & $\geq 36^{\prime \prime}$ & $\geq 48^{\prime \prime}$ \\
\hline $\begin{array}{l}\text { Running } \\
\text { Slope }\end{array}$ & $\begin{array}{l}\text { Running } \\
\text { Slope }\end{array}$ & & $\leq 8.3 \%$ or $>8.3 \%$ & $\leq 8.3 \%$ & $\leq 8.3 \%$ \\
\hline $\begin{array}{l}\text { Cross } \\
\text { Slope }\end{array}$ & Cross Slope & & $\leq 2 \%$ or $>2 \%$ & $\leq 2 \%$ & $\leq 2 \%$ \\
\hline \multirow[t]{2}{*}{$\begin{array}{l}\text { Vertical } \\
\text { Change }\end{array}$} & \multirow{2}{*}{$\begin{array}{l}\text { Vertical } \\
\text { Change in } \\
\text { Level } \\
\text { (Joint or } \\
\text { Crack) } \\
\text { Tripping } \\
\text { Hazzard } \\
\end{array}$} & \multirow[t]{2}{*}{ Across path } & $\leq 1 / 4 "$ or $>1 / 4 "$ & $\begin{array}{c}\leq 1 / 4^{\prime \prime} \\
\text { Vertical }\end{array}$ & $\leq 1 / 4^{\prime \prime}$ Vertical \\
\hline & & & $\leq 1 / 2^{\prime \prime}$ or $>1 / 2^{\prime \prime}$ & $\leq 1 / 2$ " Sloped & $\leq 1 / 2^{\prime \prime}$ Sloped \\
\hline $\begin{array}{l}\text { Horizontal } \\
\text { Opening }\end{array}$ & $\begin{array}{l}\text { Horizontal } \\
\text { Opening }\end{array}$ & $\begin{array}{l}\text { Perpendicular } \\
\text { to path }\end{array}$ & $\leq 1 / 2 "$ or $>1 / 2 "$ & $\begin{array}{c}\leq 1 / 2 " \\
\text { Opening }\end{array}$ & $\leq 1 / 2$ " Opening \\
\hline
\end{tabular}




\begin{tabular}{|c|c|c|c|c|c|}
\hline & $\begin{array}{l}\text { (Joint or } \\
\text { Grate) }\end{array}$ & & & & \\
\hline \multirow[t]{3}{*}{$\begin{array}{l}\text { Protruding } \\
\text { Object }\end{array}$} & \multirow[t]{3}{*}{$\begin{array}{l}\text { Protruding } \\
\text { Object } \\
\text { (Horizontal } \\
\text { offset) }\end{array}$} & $\begin{array}{l}\text { Sign Panel } \\
\text { (On Post, Wall, } \\
\text { Other) }\end{array}$ & $\begin{array}{l}\geq 27 " \leq 80 " \text { AWS } \\
(\text { Yes/No) } \\
\leq 4 " \\
>4 " \leq 12^{\prime \prime} \\
>12^{\prime \prime}\end{array}$ & \multirow{3}{*}{$\begin{array}{c}\geq 27 " \leq 80 " \\
\text { Above } \\
\text { Walking } \\
\text { Surface } \\
\text { (AWS) } \\
\leq 12^{\prime \prime} \text { on Post } \\
\leq 4 \text { " on Wall }\end{array}$} & \multirow[t]{3}{*}{$\begin{array}{l}\geq 27^{\prime \prime} \leq 80^{\prime \prime} \\
\text { Above Walking } \\
\text { Surface (AWS) } \\
\leq 4 " \text { on Post } \\
\leq 4 \text { " on Wall }\end{array}$} \\
\hline & & $\begin{array}{l}\text { Landscape } \\
\text { Material } \\
\text { (On Post, Wall, } \\
\text { Other) }\end{array}$ & $\begin{array}{l}\geq 27 " \leq 80 " \text { AWS } \\
(\text { Yes/No) } \\
\leq 4 " \\
>4 " \leq 12^{\prime \prime} \\
>12^{\prime \prime}\end{array}$ & & \\
\hline & & $\begin{array}{l}\text { Other } \\
\text { (On Post, Wall, } \\
\text { Other) }\end{array}$ & $\begin{array}{l}\geq 27 " \leq 80 " \text { AWS } \\
(\text { Yes/No) } \\
\leq 4 " \\
>4 " \leq 12^{\prime \prime} \\
>12 "\end{array}$ & & \\
\hline \multirow[t]{3}{*}{$\begin{array}{l}\text { Physical } \\
\text { Constraint }\end{array}$} & \multirow[t]{3}{*}{$\begin{array}{l}\text { Physical } \\
\text { Constraint }\end{array}$} & Building & $\begin{array}{l}<36 \text { " clear width } \\
\geq 36 \text { " <48" clear } \\
\text { width } \\
\geq 48 \text { " clear width }\end{array}$ & $\geq 36^{\prime \prime}$ & $\geq 48^{\prime \prime}$ \\
\hline & & Retaining Wall & $\begin{array}{l}<36 \text { " clear width } \\
\geq 36 \text { " <48" clear } \\
\text { width } \\
\geq 48 \text { " clear width }\end{array}$ & $\geq 36 "$ & $\geq 48^{\prime \prime}$ \\
\hline & & Other & $\begin{array}{l}<36 \text { " clear width } \\
\geq 36 \text { " <48" clear } \\
\text { width } \\
\geq 48 \text { " clear width }\end{array}$ & $\geq 36 "$ & $\geq 48^{\prime \prime}$ \\
\hline $\begin{array}{l}\text { Connects } \\
\text { To Other } \\
\text { Facility }\end{array}$ & $\begin{array}{l}\text { Connects To } \\
\text { Other } \\
\text { Facility }\end{array}$ & $\begin{array}{l}\text { To other } \\
\text { sidewalk, to } \\
\text { building } \\
\text { entrance, etc. }\end{array}$ & Yes/No & & \\
\hline $\begin{array}{l}\text { Sidewalk } \\
\text { Gap }\end{array}$ & $\begin{array}{l}\text { Discontinuit } \\
\text { y of } \\
\text { Sidewalk } \\
\end{array}$ & Length of Gap & $\begin{array}{l}\leq 5^{\prime} \\
>5^{\prime} \leq 10 \\
>10\end{array}$ & & \\
\hline Material & Material & & $\begin{array}{l}\text { Concrete } \\
\text { Asphalt } \\
\text { Brick } \\
\text { Other }\end{array}$ & & \\
\hline Condition & Condition & & $\begin{array}{l}\text { Good } \\
\text { Cracks } \\
\text { Dirt } \\
\text { Grass } \\
\text { Other } \\
\end{array}$ & & \\
\hline \multirow{2}{*}{$\begin{array}{l}\text { Roadway } \\
\text { Cross } \\
\text { Section }\end{array}$} & \multirow[t]{2}{*}{$\begin{array}{l}\text { Roadway } \\
\text { cross-section }\end{array}$} & $\begin{array}{l}\text { Curb and } \\
\text { Gutter }\end{array}$ & Yes / No & & \\
\hline & & Flush shoulder & Yes / No & & \\
\hline
\end{tabular}




\begin{tabular}{|c|c|c|c|c|c|}
\hline \multirow[t]{2}{*}{$\begin{array}{l}\text { Sidewalk } \\
\text { Separation }\end{array}$} & \multirow[t]{2}{*}{$\begin{array}{l}\text { Sidewalk } \\
\text { Separation }\end{array}$} & $\begin{array}{l}\text { Separated from } \\
\text { road }\end{array}$ & $\begin{array}{l}\text { Curb \& Gutter: } \\
\text { Utility Strip }<2 \text { ' or } \\
\geq 2 \text { ' } \\
\text { Flush Shoulder: } \\
\text { Utility Strip }<5 \text { ' or } \\
\geq 5 \text {, }\end{array}$ & & $\begin{array}{l}\geq 2 \text { ' if curb \& } \\
\text { gutter, or } \\
\geq 5 \text {, if flush } \\
\text { shoulder }\end{array}$ \\
\hline & & Not separated & $\begin{array}{l}\text { Curb \& Gutter: } \\
\text { Back of Curb }\end{array}$ & $\begin{array}{l}\text { Sidewalk not } \\
\text { allowed } \\
\text { adjacent to } \\
\text { flush } \\
\text { shoulder } \\
\text { roadway }\end{array}$ & $\begin{array}{l}\text { Sidewalk not } \\
\text { allowed } \\
\text { adjacent to } \\
\text { flush shoulder } \\
\text { roadway }\end{array}$ \\
\hline \multirow[t]{3}{*}{$\begin{array}{l}\text { Drop-off } \\
\text { Hazard }\end{array}$} & \multirow[t]{3}{*}{$\begin{array}{l}\text { Drop-off } \\
\text { hazard }\end{array}$} & $\begin{array}{l}>10 " \text { drop w/in } \\
24 "\end{array}$ & $\begin{array}{l}>10 " \text { drop w/in 24" } \\
\text { (Yes/No) }\end{array}$ & & $\begin{array}{l}>10 " \text { drop w/in } \\
24 "\end{array}$ \\
\hline & & $\begin{array}{l}\text { Protected by } \\
\text { railing }\end{array}$ & Yes / No & & \\
\hline & & $\begin{array}{l}\text { Other } \\
\text { protection }\end{array}$ & Yes / No & & \\
\hline \multirow[t]{8}{*}{ Obstruction } & \multirow{8}{*}{$\begin{array}{l}\text { Obstruction } \\
\text { in Sidewalk } \\
\leq 24 \text { " }\end{array}$} & Utility Pole & $<32 "$ or $\geq 32 "$ & \multirow[t]{8}{*}{$\geq 32^{\prime \prime}$} & $\geq 32 "$ \\
\hline & & Signal Pole & $\begin{array}{l}<32 " \\
\geq 32^{\prime \prime}<48^{\prime \prime} \\
\geq 48^{\prime \prime}\end{array}$ & & $\geq 48^{\prime \prime}$ \\
\hline & & Sign Post & $\begin{array}{l}<32^{\prime \prime} \\
\geq 32^{\prime \prime}<48^{\prime \prime} \\
\geq 48^{\prime \prime}\end{array}$ & & $\geq 48^{\prime \prime}$ \\
\hline & & Fire Hydrant & $<32^{\prime \prime}$ or $\geq 32^{\prime \prime}$ & & \\
\hline & & $\begin{array}{l}\text { Furniture/Ame } \\
\text { nities }\end{array}$ & $\begin{array}{l}<32 " \\
\geq 32^{\prime \prime}<48^{\prime \prime} \\
\geq 48^{\prime \prime}\end{array}$ & & $\geq 48^{\prime \prime}$ \\
\hline & & $\begin{array}{l}\text { Landscaping/H } \\
\text { ardscape }\end{array}$ & $\begin{array}{l}<32^{\prime \prime} \\
\geq 32^{\prime \prime}<48^{\prime \prime} \\
\geq 48^{\prime \prime}\end{array}$ & & $\geq 48^{\prime \prime}$ \\
\hline & & $\begin{array}{l}\text { Trees/Vegetati } \\
\text { on }\end{array}$ & $\begin{array}{l}<32^{\prime \prime} \\
\geq 32^{\prime \prime}<48^{\prime \prime} \\
\geq 48^{\prime \prime}\end{array}$ & & $\geq 48^{\prime \prime}$ \\
\hline & & Other & $\begin{array}{l}<32^{\prime \prime} \\
\geq 32^{\prime \prime}<48^{\prime \prime} \\
\geq 48^{\prime \prime}\end{array}$ & & $\geq 48^{\prime \prime}$ \\
\hline \multirow[t]{2}{*}{ Lighting } & \multirow[t]{2}{*}{ Lighting } & $\begin{array}{l}\text { Roadway/high- } \\
\text { level }\end{array}$ & Yes / No & & \\
\hline & & $\begin{array}{l}\text { Pedestrian/low- } \\
\text { level }\end{array}$ & Yes / No & & \\
\hline
\end{tabular}


Table 10: Curb Ramps \& Blended Transition Criteria

\begin{tabular}{|c|c|c|c|c|c|}
\hline \multicolumn{6}{|c|}{ Curb ramps \& Blended Transition (Intersection, Corner) (Photo) } \\
\hline Name & Description & Detail & Measurement & $\begin{array}{c}\text { ADA } \\
\text { Standard }\end{array}$ & $\begin{array}{c}\text { Public Rights- } \\
\text { of-Way } \\
\text { Accessibility } \\
\text { Guidelines } \\
\text { (PROWAG) }\end{array}$ \\
\hline $\begin{array}{l}\text { Curb } \\
\text { Ramp }\end{array}$ & Curb Ramp & $\begin{array}{l}\text { Is there a Curb } \\
\text { Ramp? }\end{array}$ & Yes/No & & \\
\hline $\begin{array}{l}\text { Running } \\
\text { Slope }\end{array}$ & $\begin{array}{l}\text { Running } \\
\text { Slope }\end{array}$ & $\begin{array}{l}\text { Slope of curb } \\
\text { ramp }\end{array}$ & $\leq 8.3 \%$ or $>8.3 \%$ & $\leq 8.3 \%$ & $\leq 8.3 \%$ \\
\hline $\begin{array}{l}\text { Counter } \\
\text { Slope }\end{array}$ & Gutter Slope & Gutter slope & $\leq 5 \%$ or $>5 \%$ & $\leq 5 \%$ & $\leq 5 \%$ \\
\hline $\begin{array}{l}\text { Cross } \\
\text { Slope }\end{array}$ & Cross Slope & Top and bottom & $\leq 2 \%$ or $>2 \%$ & $\leq 2 \%$ & $\leq 2 \%$ \\
\hline $\begin{array}{l}\text { Flare } \\
\text { Slope }\end{array}$ & Flare Slope & $\begin{array}{l}\text { Both sides of } \\
\text { ramp }\end{array}$ & $\leq 10 \%$ or $>10 \%$ & $\leq 10 \%$ & $\leq 10 \%$ \\
\hline $\begin{array}{l}\text { Ramp } \\
\text { Length }\end{array}$ & Ramp Length & $\begin{array}{l}\text { From bottom of } \\
\text { ramp to top of } \\
\text { ramp }\end{array}$ & $\begin{array}{l}<72 " \\
\geq 72 "<88^{\prime \prime} \\
\geq 88^{\prime \prime}\end{array}$ & & \\
\hline $\begin{array}{l}\text { Ramp } \\
\text { Width }\end{array}$ & Ramp Width & $\begin{array}{l}\text { At narrowest } \\
\text { point }\end{array}$ & $\begin{array}{l}<36 " \\
\geq 36 "<48 " \\
\geq 48 "\end{array}$ & $\geq 36^{\prime \prime}$ & $\geq 48^{\prime \prime}$ \\
\hline $\begin{array}{l}\text { Top } \\
\text { Landing }\end{array}$ & Top Landing & Landing Width & $\begin{array}{l}<36 " \\
\geq 36 "<48 " \\
\geq 48 "\end{array}$ & $\geq 36^{\prime \prime}$ & $\geq 48^{\prime \prime}$ \\
\hline $\begin{array}{l}\text { Bottom } \\
\text { Landing }\end{array}$ & $\begin{array}{l}\text { Bottom } \\
\text { Landing }\end{array}$ & Landing Width & $<48$ " or $\geq 48 "$ & $\geq 48^{\prime \prime}$ & $\geq 48^{\prime \prime}$ \\
\hline \multirow[t]{2}{*}{$\begin{array}{l}\text { Detectable } \\
\text { Warnings }\end{array}$} & \multirow[t]{2}{*}{$\begin{array}{l}\text { Detectable } \\
\text { Warnings }\end{array}$} & $\begin{array}{l}\text { Truncated } \\
\text { Domes }\end{array}$ & Yes/No & & \\
\hline & & $\begin{array}{l}\text { Color: } \\
\text { • Brick Red, } \\
\text { Yellow, } \\
\text { Black, No } \\
\text { Color, Other }\end{array}$ & Yes/No & & \\
\hline $\begin{array}{l}\text { Detectable } \\
\text { Warning }\end{array}$ & $\begin{array}{l}\text { Detectable } \\
\text { Warnings } \\
\text { Placement }\end{array}$ & $\begin{array}{l}\text { Detectable } \\
\text { Warnings } \\
\text { Placement }\end{array}$ & $\begin{array}{l}\leq 2 \text { " from back of } \\
\text { curb } \\
>2 " \leq 5 \text {, from back } \\
\text { of curb } \\
>5 \text { ' from back of } \\
\text { curb }\end{array}$ & $\begin{array}{l}\leq 2 \text { " from } \\
\text { Back of curb } \\
\text { or } \\
\leq 5 \text {, from } \\
\text { Curb }\end{array}$ & $\begin{array}{l}\leq 2 \text { " from Back } \\
\text { of curb } \\
\text { or } \\
\leq 5 \text {, from Curb }\end{array}$ \\
\hline $\begin{array}{l}\text { Type of } \\
\text { Ramps }\end{array}$ & $\begin{array}{l}\text { Type of } \\
\text { Ramps }\end{array}$ & & $\begin{array}{l}\text { Perpendicular } \\
\text { Parallel } \\
\text { Combination } \\
\text { Diagonal } \\
\text { Other }\end{array}$ & & \\
\hline
\end{tabular}


Table 11: Street Crossing Criteria

\begin{tabular}{|c|c|c|c|c|c|}
\hline \multicolumn{6}{|c|}{ Street Crossing (Intersection, Location) (Photo) } \\
\hline Name & Description & Detail & Measurement & ADA Standard & $\begin{array}{c}\text { Public Rights- } \\
\text { of-Way } \\
\text { Accessibility } \\
\text { Guidelines } \\
\text { (PROWAG) }\end{array}$ \\
\hline $\begin{array}{l}\text { Street } \\
\text { Crossing }\end{array}$ & $\begin{array}{l}\text { Street } \\
\text { Crossing }\end{array}$ & $\begin{array}{l}\text { Is there a } \\
\text { Marked } \\
\text { Crossing? }\end{array}$ & Yes/No & & \\
\hline $\begin{array}{l}\text { Horizontal } \\
\text { Opening }\end{array}$ & $\begin{array}{l}\text { Horizontal } \\
\text { Opening } \\
\text { (Joint or } \\
\text { Grate) } \\
\end{array}$ & $\begin{array}{l}\text { Perpendicular } \\
\text { to path }\end{array}$ & $\leq 1 / 2 "$ or $>1 / 2 "$ & $\leq 1 / 2 "$ & $\leq 1 / 2 "$ \\
\hline \multirow[t]{2}{*}{ Median } & \multirow[t]{2}{*}{ Island/Median } & & Yes/No & & \\
\hline & & $\begin{array}{l}\text { Pedestrian } \\
\text { Refuge }\end{array}$ & $\begin{array}{l}60 " \text { deep x 60" } \\
\text { wide (Yes/No) } \\
48 " \text { deep x 60" } \\
\text { wide (Yes/No) }\end{array}$ & $\begin{array}{l}48 " \text { deep x 60" } \\
\text { wide }\end{array}$ & $\begin{array}{l}\text { 60" deep x 60" } \\
\text { wide }\end{array}$ \\
\hline \multirow[t]{8}{*}{$\begin{array}{l}\text { Pedestrian } \\
\text { Signal }\end{array}$} & \multirow[t]{6}{*}{$\begin{array}{l}\text { Pedestrian } \\
\text { Signal }\end{array}$} & $\begin{array}{l}\text { Is there a push- } \\
\text { button? }\end{array}$ & Yes/No & & \\
\hline & & Push-button & $\begin{array}{l}\text { 2" dia. raised } \\
\text { (Yes/No) }\end{array}$ & & 2" dia. raised \\
\hline & & $\begin{array}{l}\text { Accessible } \\
\text { Features }\end{array}$ & $\begin{array}{l}\text { Audible } \\
\text { Tactile } \\
\text { Other } \\
\text { None } \\
\end{array}$ & & \\
\hline & & $\begin{array}{l}\text { Height of } \\
\text { Button }\end{array}$ & $\begin{array}{l}\leq 42 " \text { AWS } \\
>42 " \leq 48 " \text { AWS } \\
>48 " \text { AWS }\end{array}$ & $\leq 48 "$ AWS & $\leq 42 "$ AWS \\
\hline & & $\begin{array}{l}\text { Level Clear } \\
\text { Space }\end{array}$ & $\begin{array}{l}\geq 30 " x 48 " \\
\text { (Yes/No) }\end{array}$ & $\geq 30 " x 48 "$ & $\geq 30 " x 48 "$ \\
\hline & & $\begin{array}{l}\text { Number of } \\
\text { Lanes to Cross }\end{array}$ & $\begin{array}{l}1,2,3,4,5,6,7 \\
8,9,10\end{array}$ & & \\
\hline & & $\begin{array}{l}\text { Total Time to } \\
\text { Cross }\end{array}$ & Seconds & & \\
\hline & & $\begin{array}{l}\text { Measured on } \\
\text { "Date" at } \\
\text { "Time" }\end{array}$ & Date-Time Stamp & & \\
\hline Material & Material & & $\begin{array}{l}\text { Concrete } \\
\text { Asphalt } \\
\text { Brick/Paver } \\
\text { Other } \\
\end{array}$ & & \\
\hline
\end{tabular}




\begin{tabular}{|l|l|l|l|l|l|}
\hline Condition & Condition & Good & & \\
& & Cracks & & \\
& & Faded & Other & & \\
\hline
\end{tabular}

The main elements considered in the design of the SAPFIM application are illustrated in Figure 1. The diagram starts with the Planning of the software that sets the vision of the expected outcome. This phase will be based on the experience of the research team with feedback from all the participants in this research project. Then, the SAPFIM Criteria outlines the data that will need to be collected in the field and measured using the ADA and PROWAG standards. The criteria will also be used for the development of the SAPFIM database. Once the previous steps are completed, the Web Design will start. The web application will consist of four (4) sections that will be created for the collection of data, management, and assessment of pedestrian facilities. Those sections include:

1. Data Collection

2. Reports

3. Data Management

4. Maps

In the Data Collection section, users through the user interface will collect sidewalks, ramps, and street crossing data. Data will be uploaded directly into the SAPFIM web server and can be collected using field devices that have GPS, camera, and wireless capabilities. If necessary, office computers can also be used to input or correct some of the information collected in the field.

Under Reports, users will be able to generate and print reports such as full report for each of the three pedestrian categories: sidewalks, ramps, and street crossings. In addition, a report that measures the compliance of pedestrian facilities with ADA and PROWAAG will be included in the software application. This feature can assist the agencies using SAPFIM with identifying the data records that do not comply with ADA or PROWAAG standards, which can be very helpful for prioritizing improvements and complying with ADA requirements.

In the data management section, users will be able to generate queries based on the data available in the database. Data can be exported in CSV format for use in other software applications; pictures will be exported in JPG format.

The Maps section will allow users to view and print the collected pedestrian facilities using Google Map. Users will also be able to navigate on the map to get information by clicking on the appropriate icons that represent the sidewalks, ramps, and street crossings data collected. 


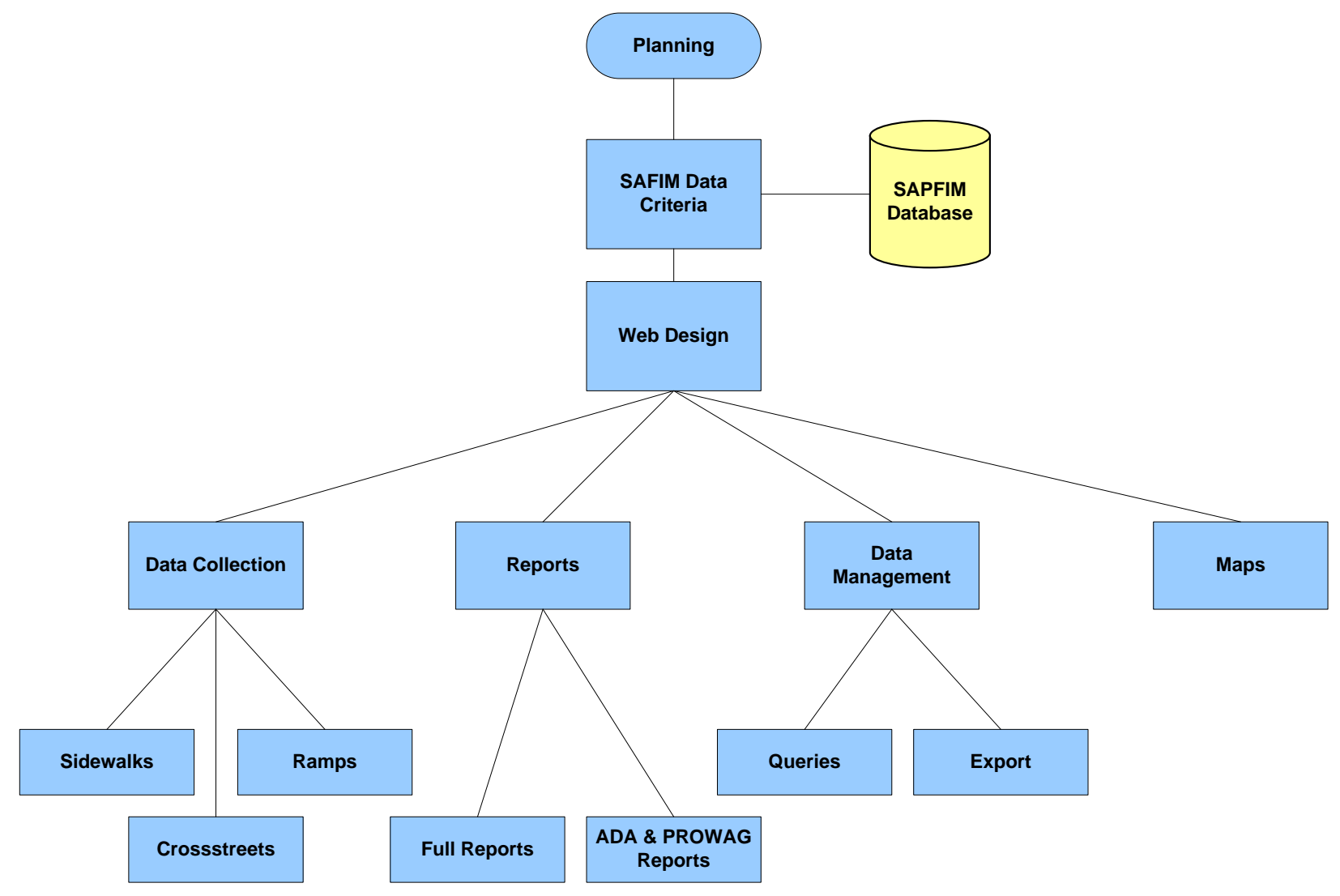

Figure 1: Design of SAPFIM Web Application

\section{DATA FLOW OF SAPFIM}

This section describes the SAPFIM process and data flow. Users will be able to access SAPFIM through a web browser using a computer, tablet, smartphone, or laptop. In the field, users will be able to collect new data or modify an existing pedestrian data point from the database. Once a data record is retrieved, it can be edited. After the sidewalk information has been updated, a user will be able to save it to the database.

Figure 2 shows the process and data flow functions of SAPFIM. It depicts how users using various devices or computers will be able to upload data or retrieve information through the internet by accessing the database by means of the SAPFIM application hosted in the web server. 


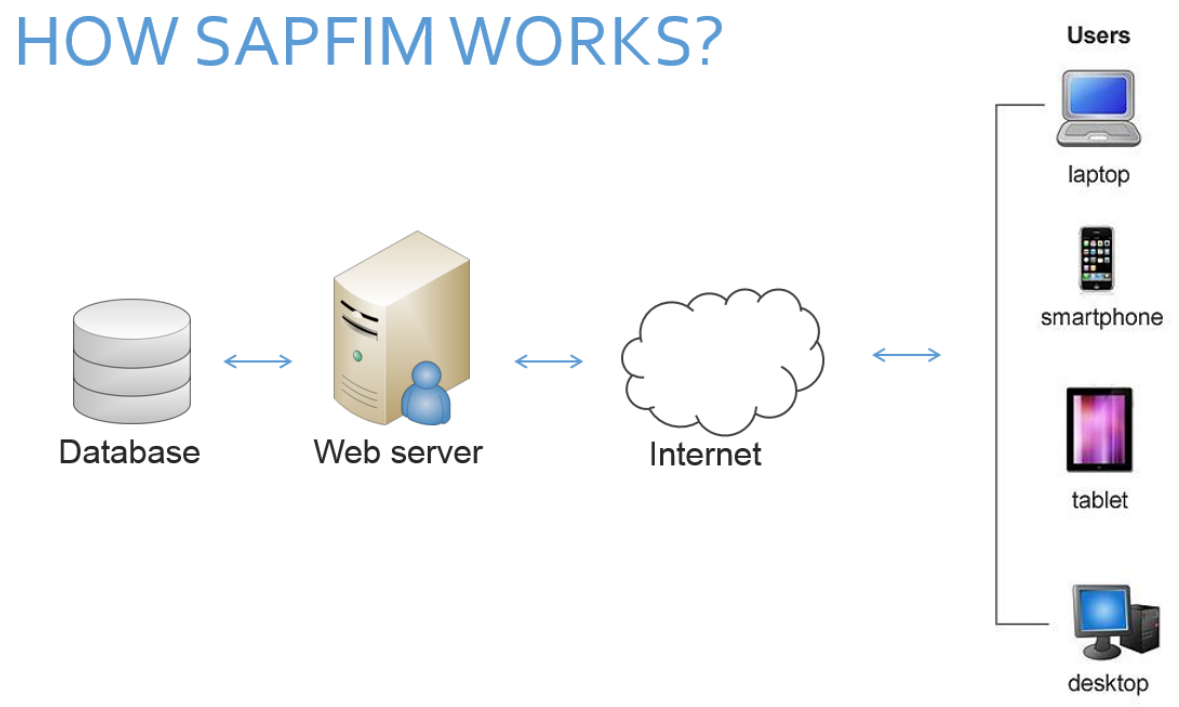

Figure 2: SAFIM Data Flow Diagram 


\section{NEXT STEPS}

This section presents the next steps towards the development of SAPFIM, as presented in the scope of work of the "Safe and Accessible Pedestrian Facilities Inventory Model (SAPFIM): Development" project funded by the National Center for Transportation Research (NCTR).

The main objective is to develop a web-based software application that local agencies can use for the collection, storage, querying, analysis, and reporting of pedestrian facilities. It will include accessible and safety features associated with sidewalks, curb ramps, and street crossings. Data will be collected using devices, (i.e., tablets with GPS, camera, and wireless capability) which can be uploaded directly into the web server.

To achieve this, the FIU research team proposes a series of work tasks that include software development and testing and producing a final report.

\section{- Prepare the Project Work Plan for the Development of SAPFIM}

This task will serve as a general guideline for all the milestones according to the proposed schedule.

\section{- Develop the SAPFIM Software}

As part of this task, a web-based pedestrian facility application will be developed using Microsoft Visual Studio to collect data from pedestrian facilities in order to efficiently assess the conditions of pedestrian facilities such as sidewalks along public rights of way.

\section{○ Database}

This includes the creation and setup of the SQL server database using Microsoft SQL Server, which will be the back end of the software application.

\section{○ User Interface}

In this step, the user interface of the web application will be created.

\section{- Test and Troubleshoot the Web Application}

This task includes an overall testing of software such as device testing, wireless communication testing, database testing, which will ensure that the software is bug free and provides opportunities to improve the application. 


\section{- Prepare the Final Report}

A draft final report documenting all aspects of this research will be prepared and submitted to NCTR for review and comments. This will include the work plan, the development of the software, and the results from the software testing. The final report will provide the information gathered for the development of the Safe and Accessible Pedestrian Facilities Inventory Model (SAPFIM). Based on the feedback from NCTR, the report will be revised and finalized, and resubmitted. 


\section{REFERENCES}

AARP, WALC (2014). Sidewalks: A Livability Fact Sheet. American Association of Retired Persons and Walkable and Livable Communities Institute. http://www.aarp.org/content/dam/aarp/livable-communities/documents2014/Livability\%20Fact\%20Sheets/Sidewalks-Fact-Sheet.pdf

AASHTO Executive Committee. (1999). "Guide for the Development of Bicycle Facilities." American Association of State Highway and Transportation Officials, Washington, DC.

AASHTO (2004). Guide for the Planning, Design, and Operation of Pedestrian Facilities. American Association of State Highway and Transportation Officials.

AASHTO (2012). Guide for the Development of Bicycle Facilities. American Association of State Highway and Transportation Officials.

ACHD (2005). Pedestrian-Bicycle Transition Plan. Ada County Highway District (ACHD), Idaho. Report prepared by the Transpo Group. http://www.achdidaho.org/Departments/PP/PedBike_Plan.aspx

Allan, B., \& Moffett, F. C. (1998). Accessibility Design for All: An Illustrated Handbook: Washington State regulations (WAC 51-40). Olympia, WA (Capitol Court, Suite 237, 1110 Capitol Way, S., Olympia 98501-2272): A.I.A., Washington Council.

American National Standards Institute (ANSI) (1998). Accessible and Usable Buildings and Facilities. The Council.

Americans with Disabilities Act of 1990: Law and Explanation. (1990). Chicago, Ill. (4025 W. Peterson Ave., Chicago 60646): Commerce Clearing House.

Bicycle, Oregon, and Pedestrian Plan. "Oregon Department of Transportation." Salem, OR (1995).

Boatman|, B. M. (2015). Los Angeles Will Fix Crumbling, Inaccessible Sidewalks - New Mobility. Retrieved October 18, 2016, from http://www.newmobility.com/2015/04/los-angeleswill-fix-crumbling-inaccessible-sidewalks/

Designing Walkable Urban Thoroughfares: A Context Sensitive Approach. (2010). Washington, DC: Institute of Transportation Engineers.

Federal Highway Administration (FHWA) (2001). Accessible Sidewalks and Street Crossings: An Informational Guide. 1200 New Jersey Avenue, SE Washington, DC 20590 USA. http://www.bikewalk.org/pdfs/sopada_fhwa.pdf 
Federal Highway Administration (FHWA) (2013). A Guide for Maintaining Pedestrian Facilities for Enhanced Safety. No. FHWA-SA-13-037.

Federal Highway Administration (FHWA). Designing Sidewalks and Trails for Access https://www.fhwa.dot.gov/environment/bicycle_pedestrian/publications/sidewalks/contents.cfm

Goldman, Charles D. Architectural Barriers: A Perspective on Progress. W. New England Law Review 5 (1968): 465.

Florida Department of Transportation. (2016). FDOT Americans with Disabilities Act (ADA): ADA / Accessibility Program. http://www.fdot.gov/designsupport/ADA/

International Code Council, Inc. (2016). ICC A117.1 Standard Fourth Public Review Draft Background Report. ICC/ANSI A117.1 Standard Development - 2015 Edition http://productionpullzone.umz7izwbxixtqs4tn8wkvgdcktq5y5tafr.netdna-cdn.com/wpcontent/uploads/asc_a117/A117-1-Fourth-Public-Review-Draft.pdf

ITE (1998). Design and Safety of Pedestrian Facilities. Institute of Transportation Engineers. Traffic Engineering Council Committee TENC 5A-5.

ITE (2010). Designing Walkable Urban Thoroughfares - A Context Sensitive Approach: An ITE Recommended Practice. Institute of Transportation Engineers.

Keim, Donald W. (1976). "Education of all Handicapped Children Act of 1975, University of Michigan, JL Reform 10: 110.

Kockelman, K., Zhao, Y., Heard, L., Taylor, D., \& Taylor, B. (2000). The Nature of ADA's Sidewalk Cross-Slopes Requirements: A Review of the Literature. Transportation Research Record, 1705, 53-60.

LaPlante, J. N., and Short, T. R. (2000). AASHTO GUIDE FOR THE PLANNING, DESIGN AND OPERATION OF PEDESTRIAN FACILITIES. Institute of Transportation Engineers.

NACTO (2010). Urban Bikeway Design Guide. National Association of City Transportation Officials

NACTO (2014). Urban Bikeway Design Guide, Second Edition. National Association of City Transportation Officials.

National Council on Disability (2004). Livable Communities for Adults with Disabilities.

Oberlink, M. "Livable communities for adults with disabilities." Policy brief (Center for Home Care Policy and Research (US)) 29 (2005): 1-6.

PACTS (2014). Regional Bicycle and Pedestrian Facility Design Guidance for the PACTS Metropolitan Planning Area. Portland Area Comprehensive Transportation System. Report 
prepared by Alta Planning + Design. http://www.pactsplan.org/plans-studies/2013-plans-studiescompleted/

Pedestrian Guidebook Facilities (1997). Incorporating Pedestrians into Washington's Transportation System. Prepared by Otak for Washington State DOT, Olympia, WA.

PennDOT (2016). Design Manual Part 2 Highway Design. Publication 13M, 2015 Edition Change No. 1. Pennsylvania Department of Transportation. https://www.dot.state.pa.us/public/ pubsforms/Publications/PUB\%2013M.pdf

Perkins, Dean. (2015). ADA for Roadway Design: Incorporating PROWAG. Design Training Expo. http://www.fdot.gov/design/Training/DesignExpo/2015/presentations/ADAandPROWAGDeanPerkins.pdf

Rehabilitation Act of 1973 (1998). https://www.disability.gov/rehabilitation-act-1973/ Revised Code of Washington. Vol RCW 70.010 (1992). Washington Electronic Authentication Act.

Savage, Joseph P., MacDonald, David R., and Ewell John. (1994). A Guidebook for Residential Traffic Management. Olympia, WA: Washington State Department of Transportation.

United States Access Board (1991). The Americans with Disabilities Act Accessibility Guidelines (ADAAG). Amended in 2002. https://www.access-board.gov/guidelines-andstandards/buildings-and-sites/about-the-ada-standards/background/adaag

United States Access Board (2004). Americans with Disabilities Act and Architectural Barriers Act Accessibility Guidelines. Amended in 2014. https://www.access-board.gov/attachments/ article/412/ada-aba.pdf

United States Access Board. (2006). ADA Standards for Transportation Facilities. https://www.access-board.gov/guidelines-and-standards/transportation/facilities/ada-standardsfor-transportation-facilities

United States Access Board. (2006). Americans with Disabilities Act (ADA) Standards for Transportation Facilities. https://www.accessboard.gov/attachments/article/1417/ADAdotstandards.pdf

United States Access Board (2010). Guide to the ADA Standards. https://www.accessboard.gov/guidelines-and-standards/buildings-and-sites/about-the-ada-standards/guide-to-theada-standards

United States Access Board (2011). Proposed Accessibility Guidelines for Pedestrian Facilities in the Public Right-of-Way. https://www.access-board.gov/attachments/article/743/nprm.pdf

United States Congress. "Intermodal surface transportation efficiency act of 1991." Public Law (1991): 102-240. 
United States Congress. "Transportation Equity Act for the 21st Century." Public Law (1998): 105-178.

United States Department of Justice Civil Rights Division. (2016). Information and Technical Assistance on the Americans with Disabilities Act. https://www.ada.gov/

United States Department of Transportation. Accessibility: Equal Access to Transportation. https://www.transportation.gov/accessibility

WALC (2014). Observations and Recommendations: The Built Environment. Albuquerque, New Mexico. Walkable and Livable Communities Institute.

Zhang, Y., Proulx, F. R., Ragland, D. R., Schneider, R. J., \& Grembek, O. (2014). Develop a Plan to Collect Pedestrian Infrastructure and Volume Data for Future Incorporation into Caltrans Accident Surveillance and Analysis System Database. Prepared by the UC Berkeley Safe Transportation Research and Education Center for the California Department of Transportation (Caltrans). 